\title{
周王纪年考证校补
}

\begin{abstract}
张鹏程
摘要: 西周是中华文明发展过程中的重要时代。这一时期的思想文化及典章制度对后来的中国 和东亚社会产生了持久而深远的影响。遗荅的是, 西周的确切纪年早在西汉就已失传。两千余 年来，虽有古今中外众多学者考证求索，但是西周王年至今仍未有定论。本文通过对八十一条 四要素俱全的金文历日进行系统性的分析，比较其相互匹配的情况，从而推断得出金文记日用 语最合理的理解方式。在此基础上, 结合出土材料与文献记载, 拟定了上起文王受命元年、下 至平王崩年的完整周王纪年。推算的结果揭示周王纪年曾出现七年的中断, 进而解释了为何出 土的材料不能与《史记》年表相合。本文的推算结果与考古证据、文字材料以及古代天象均能 够高度契合，可为古史研究提供可靠的年代框架，有助于进一步探究中华文明的起源。
\end{abstract} 关键词: 初吉 既生霸 既望 既死霸 西周年代

（联系方式/Contact Info：pczhang.tony@gmail.com）

\section{A Reconstruction of}

\section{the Lost Chronology of Zhou}

\section{Pengcheng Zhang}

Abstract: The first half of the Zhou Dynasty, known as Western Zhou, was a critical formative period of Chinese civilization. Western Zhou introduced philosophical ideas, cultural motifs, governing practices, and social institutions that have had a profound and lasting impact on Chinese and East Asian societies. Unfortunately, only a partial chronology of this time period survives. Recovering the absolute dates of Western Zhou has since become a classical question that remained unresolved for over two millennia. Here I report a successful reconstruction of this long-sought chronology using archaeoastronomical methods. Systematic analysis of the relative compatibility of all 81 known fully-dated bronze inscriptions revealed the definitions of the lunar phase terms, which enabled computation of absolute dates. These calculations, combined with available archaeological and textual evidence, produced a complete chronology starting in the year King Wen received the Mandate of Heaven and ending in the year of King Ping's death. The results also reveal a previously unknown seven-year gap in the regnal years of Zhou, which explains the inconsistencies between excavated material and the annals of Shiji. The complete chronology reported here is highly consistent with archaeological evidence, textual records, and astronomical events, thus providing a reliable temporal framework for studying ancient Chinese history, and facilitating a deeper understanding of the origins of Chinese civilization.

Key Words: Chuji, Jishengba, Jisiba, Jiwang, Western Zhou chronology 


\section{引言}

西周是中国历史上一个非常重要的时期。它继承、吸收了殷商发达的青铜文明，并对其作 出了重大的改革与发展, 奠定了此后三千余年中华文明的基调, 亦由此对整个东亚都产生了极 为深远的影响。遗憾的是, 由于战乱和秦火, 西周的确切年代早在汉代就已失传。自此以后, 推算、还原西周年代就成为中国历史的重大课题。

司马迁撰写《史记》时，还能见到不少记载了上古史事的文献。但是这些材料却相互冲 突。(1) 太史公本着 “疑则传疑” 的严谨态度，只从西周晚期的共和元年 (相当于公元前 841 年 ) 开始编列史事年代。此后两千余年，学者们试图继续将年代上推，却遇到了诸多困难。

传世文献当中虽然有不少关于西周的记载，但是其中可用于推算年代的信息却十分有限。 即便根据文献中的零星记载进行年代推算, 还必须面对文献本身是否可靠的质疑: 今天所能见 到的文献资料, 其成书年代均晚于西周, 在撰写和流传的过程当中可能存在讹误、篡改乃至伪 作的情况，未必真实地反映了西周当时的情形，不可轻信。

自宋代以来陆续出土了大量的西周青铜器, 其上多铸刻有铭文, 称为金文。这些文物制作 于当时、埋藏于地下，因此是可靠的原始材料。根据器物的形制、纹饰以及铭文的字体风格、 行文内容等信息, 可以推断器物所处的大致时代。金文中有时还会记录当时的历日信息。其中 一部分历日除了王年、月序、日干支之外，还包含一个专门的记日用语，一般认为是用来描述 月相的, 故也称为月相术语。王年、月序、日干支以及记日用语统称为金文历日的 “四要 素”。

理论上来说，如果知道了金文历日的四要素信息，就可以根据月序、月相及干支来推算历 日的绝对日期, 再根据王年来安排年代。然而, 这个方法面临以下难题: 其一、历日只记录在 位周王的纪年, 除个别情况外, 所属王世不明; 其二、由于西周的历法尚不明确, 不清楚月序 指的是一年中的哪个时段; 其三、记日用语的确切含义已经失传，其描述的月相未知; 其四、 不知道西周诸王的在位时长。西周诸王, 传世文献当中只明确记载了幽王、宣王以及穆王的在 位时长。西晋时发现的《汲冢竹书》中涉及穆王的记载与传世文献有出入, 2 故本文视穆王的 在位时长为未知。2003 年陕西眉县出土了 27 件悎藏青铜器, 皆有铭文。其中包括两组佐鼎 12 件以及一件佐盘。由佐盘铭文可知这些佐器在西周晚期的宣王世。(3) 然而, 两组佐鼎的铭文历 日与《史记》所载的宣王年代不合, (4) 则文献所载的宣王、幽王年代也未必可信。此外, 西周 历法是否以新月 (朔日) 为月初还有争议。

在这种情况下，要用金文历日推算年代，就必须先对西周历法以及记日用语的含义作出假 设。基于所作的假设，可根据四要素信息推算、安排历日的年代。显然，同样的历日信息，基 于不同的假设，会推算得到不同的结果。这就导致西周的确切年代一直众说纷纭、莫衰一是。

(1) 《史记 -三代世表》: “余读谍记, 黄帝以来皆有年数。稽其历谱谍终始五德之传, 古文咸不同, 乘异。” 见《史记》卷 13 , 北京: 中华书局, 2013 年点校本二十四史修订本，第 2 册第 618 页。

(2) 《晋书・束晳传》: “自周受命, 至穆王百年, 非穆王寿百岁也。” 见《晋书》卷 51 , 北京: 中华书局, 1974 年点校本, 第 5 册第 1432 页。

(3) 李学勤: 《眉县杨家村新出青铜器研究》, 《文物》2003 年第 6 期。

(4) 张培瑜: 《速鼎的月相纪日和西周年代》, 《文物》2003 年第 6 期。 
如果将推算西周年代类比为一道数学题, 那么这道题两千余年未能求解的原因在于未知的 因素太多。虽然如此，有一点是可以确知的：这道题必有唯一解，因为必然存在一份正确的西 周历谱。这意味着，存在一种历法规则和金文记日用语的理解方式，可以将全部金文历日按照 其四要素信息合理地安排年代, 且所得结果和器物形制、纹饰以及铭文字体、行文内容等信息 相符合。本文从这一基本认知出发，由金文历日的相互关系入手，推算、编拟周王年代方案。

\section{材料与方法}

\section{推算的年代范围}

年代范围的下限即是推算起点。以往依据《史记・十二诸侯年表》, 将共和元年视为最早 的可信纪年，作为推算的起点。然而，现在知道出土材料与《史记》记载的年代信息有冲突。 因此必须找到可靠的、可验证的推算起点。据《春秋・隐公三年》经, “王二月己巳, 日有食 之。” (1) 当年平王崩。经天文推算可知这次日食发生在公元前 720 年 2 月 22 日。(2) 由此可以 确立平王崩年的绝对年代。本文以此作为推算起点, 将此前的年代全部视为未知。这意味着, 连一般认为确定的东周平王的年代，本文也视作未定，将与西周年代一并推算。

年代范围的上限不得晚于西周始年。古今中外多位学者都曾尝试推算武王克纣的年代，有 四十余种不同的说法，年代最晚为公元前 1018 年，最早达公元前 1130 年。(3) 本文因此选取公 元前 1150 年作为推算的上限。

由此，将推算的年代范围限定在公元前 1150 年至公元前 720 年之间（含首尾之年）。 计算朔望与分至时刻

采用 Python 编程语言的 Skyfield 扩展包，(4) 依据美国国家航空航天局（NASA）下属喷气 推进实验室（JPL）制订的 DE431 星历表，(5) 计算推算年代范围内所有的新月、上弦月、满 月、下弦月以及春分、夏至、秋分、冬至的时刻。日期采用儒略历日期，时刻均转换为西安 （北纬 $34^{\circ} 20^{\prime}$ 、东经 $108^{\circ} 56^{\prime}$ ) 当地时间。为了提高运算效率，用 NumPy 扩展包进行向量 运算、(6) 用 Pandas 扩展包进行数据操作。(7)

(1) 《春秋左传正义》卷 3, 《十三经注疏》, 北京: 北京大学出版社, 2000 年整理本, 第 16 册第 78 页。

(2) 陈遵协: 《中国天文学史》，上海：上海人民出版社，2006 年，第 623 页。

(3) 详见北京师范大学国学研究所编: 《武王克商之年研究》, 北京: 北京师范大学出版社, 1997 年, 第 687690 页。

(4) Brandon Rhodes, http://rhodesmi11. org/skyfield.

(5) William M. Folkner et al., “The Planetary and Lunar Ephemerides DE430 and DE431”, IPN

Progress Report, vol. 42, no. 196 (February, 2014), pp. 1-81.

(6) Stéfan van der Walt et al., "The NumPy Array: A Structure for Efficient Numerical

Computation”, Computing in Science \& Engineering, vol. 13, no. 2 (March-Apri1, 2011), pp. 22-30.

(7) Wes McKinney, "Data Structures for Statistical Computing in Python", Proceedings of the 9th Python in Science Conference, SciPy 2010 (June-July, 2010), pp. 51-56. 


\section{拟定参考历谱}

假定周历以建子之月为正月岁首。(1) 由于计算北斗斗柄的指向比较复杂，本文在拟定参考 历谱时以每年冬至 (太阳位于黄经 $270^{\circ}$ ) 所在的那个月为建子之月, 作为当年正月, 然后依次 排定二月、三月，直至岁末。由于冬至可由天文反演求得，故推算的年代范围内每年的正月都 可确定，相应地每年有十二个月还是十三个月也就确定了。采用这种方式排定的月序，虽然将 闰月置于岁末，但是本质上采用的是无中气置闰法。

西周历法每个月的第一天是朔日还是朏日尚有争议。由于计算朏日比较复杂，本文在拟定 参考历谱时暂以朔日为每个月的第一天。如果每个月的第一天其实在朏日，那么朔日应当出现 在月末，而非月初。这可以通过推算的结果来检验。

按照上述历法规则，拟定推算起止年代范围内的参考历谱。

\section{检索符合历日信息的日期}

给定了金文记日用语的理解方式，结合历日的月序、日干支，可根据参考历谱检索获得推 算年代范围内所有满足条件的日期。由历日的王年，可进一步求得对应的元年，称为该历日的 适配元年。考虑到肉眼观象或者推步制历的误差，允许月相有一日误差。考虑到西周历法确定 岁首以及添置闰月的误差，允许月序有一个月的误差：月序无误者，称 “建正” ; 有月序误差 者, 若前、后月均可相合, 称 “错月” ; 若只能与前月相合, 称 “失闰” （西周历此前某年比 参考历谱少置一闰月）; 若只能与后月相合，称 “超闰”（西周历此前某年比参考历谱多置一 闰月）。

\section{系统性比对、安排历日年代}

求得所有金文历日在推算年代范围内的全部适配元年之后，就可以比对不同的历日之间的 相互关系，来安排历日的年代。有相同适配元年的金文历日可以排入同一王世，没有相同适配 元年的金文历日则不能相容于同一王世。王年相同而月序误差不同的历日不能置于同一年 ( 某 年若与某历日建正相合，则不能与另一历日错月相合）。

在满足历日的四要素信息的基础之上，还必须符合根据器物的形制、纹饰，铭文的字体风 格等信息推断的器物的大致时代。即, 不能为了合历而将典型的西周晚期铜器安排在西周中早 期。此外, 还必须顾及不同器铭之间的人物关联, 如西周中期多器铭文提及共同的人物, 则这 些器物的年代间隔必须合理。又如, 不同器器主之间若有明确的父子先后关系, 在安排器物年 代时也必须遵循。

最终, 在符合出土材料的前提下, 尽量满足文献的记载。如果出土材料与文献的记载出现 矛盾，则说明文献的记载不可靠。

(1) 《史记・历书》: “昔自在古, 历建正作于孟春……抚十二节, 卒于丑……夏正以正月, 殷正以十二月, 周 正以十一月”，见《史记》卷 26, 第 4 册第 1493-1497 页。据此, 夏正建寅、殷正建丑、周正建子。 


\section{检验与修正推算假设}

如果有金文历日无法根据其四要素信息安排年代，或者安排的年代与其它信息（器物的大 致时代、铭文的人物关联 ) 有冲突，则意味着推算所作的假设当中有不合理之处，必须仔细辨 析、予以修正。再用修正之后的新假设重复上述排历、检索、比对的步骤。如此循环, 直至全 部金文历日都可以得到合理的安排。

\section{金文历日}

笔者搜集、整理了王年、月序、日干支、记日用语四要素俱全的金文历日共计 81 条，列于 下表。绝大多数的历日信息没有歧义，但是有个别情形需要辨析，详见相关注释。按照记日用 语分类，计初吉 36 条、既生霸 24 条、既望 16 条、既死霸 5 条。在推算的时候不对金文历日信 息作任何改动。

表 1 金文历日信息一览表

\begin{tabular}{|c|c|c|c|c|c|c|}
\hline 器名 & 铜器断代 & 年祀 & 月序 & 记日用语 & 干支 & 著录 \\
\hline 师鼣篮 & 晚期 & 元年 & 正月 & 初吉 & 丁亥 & 《集成》 (1) 4311 \\
\hline 师言筬 & 晚期 & 元年 & 二月 & 既望 & 庚寅 & 《商周》(2) 5402 \\
\hline 逆钟 & 晚期 & 元年 & 三月 & 既生霸 & 庚申 & 《集成》60-63 \\
\hline 元年师旅筬 & 晚期(3) & 元年 & 四月 & 既生霸 & 甲寅(4) & 《集成》4279-4282 \\
\hline 元年师兑篮 & 晚期 & 元年 & 五月 & 初吉 & 甲寅 & 《集成》4274-4275 \\
\hline 郑季盨 & 晚期 & 元年 & 六月 & 初吉 & 丁亥 & 《集成》4454-4457 \\
\hline 师虎筬 & 中期 & 元年 & 六月 & 既望 & 甲戌 & 《集成》4316 \\
\hline 舀鼎 1 & 中期 & 元年 & 六月 & 既望 & 乙亥 & 《集成》2838 \\
\hline 舀鼎2 & 中期 & 前一年(5) & 四月 & 既生霸 & 丁酉(6) & 同上 \\
\hline 伯吕父盪 & 晚期 & 元年 & 六月 & 既生霸(7) & 庚戌 & 《商周》5635 \\
\hline 师影筬 & 晚期 & 元年 & 九月 & 既望 & 丁亥 & 《集成》4312 \\
\hline 咽籃 & 晚期 & 二年 & 正月 & 初吉 & 丁亥(8) & 《集成》4297 \\
\hline 吴方彝盖 & 中期 & 二祀 & 二月 & 初吉 & 丁亥 & 《集成》9898 \\
\hline 趩觯 & 中期 & 二祀 & 三月 & 初吉 & 乙卯 & 《集成》6516 \\
\hline 王臣筬 & 中期 & 二年 & 三月 & 初吉 & 庚寅 & 《集成》4268 \\
\hline 三年师兑筬 & 晚期 & 三年 & 二月 & 初吉 & 丁亥 & 《集成》4318-4319 \\
\hline 表卫盉 & 中期 & 三年 & 三月 & 既生霸 & 壬寅 & 《集成》9456 \\
\hline 师晨鼎 & 中期 & 三年 & 三月 & 初吉 & 甲戌 & 《集成》2817 \\
\hline
\end{tabular}

(1) 中国社会科学院考古研究所编: 《殷周金文集成》, 北京: 中华书局, 2007 年修订增补本。

(2) 吴镇烽编著: 《商周青铜器铭文暨图像集成》, 上海: 上海古籍出版社, 2012 年。

(3) 《集成》定为西周晚期, 《商周》（器号 5331-5334）定为西周中期后段。

(4) 铭文作 “唯王元年四月既生霸, 王在淢应。甲寅, 王格庙, 即位” , 笔者以 “既生霸” 为甲寅日的记日用 语。

(5) 若 “既望” 在下半月, 则六月乙亥与四月丁酉不得同年。笔者以六月乙亥在四月丁西之来年。

(6) 铭文作 “唯王四月既生霸, 辰在丁酉”, 笔者以此句 “既生霸” 为丁酉日的记日用语。

(7) 铭文作 “既青霸” ，笔者理解为 “既生霸”。

(8) 铭文作 “唯二年正月初吉, 王在周昭宫。丁亥, 王格于宣榭”, 笔者以此句 “初吉” 为丁亥日的记日用语。 


\begin{tabular}{|c|c|c|c|c|c|c|}
\hline 器名 & 铜器断代 & 年祀 & 月序 & 记日用语 & 干支 & 著录 \\
\hline 师俞筬盖 & 中期(1) & 三年 & 三月 & 初吉 & 甲戌 & 《商周》5330 \\
\hline 师遽籃盖 & 中期 & 三祀 & 四月 & 既生霸 & 辛西 & 《集成》4214 \\
\hline 柞钟 & 晚期 & 三年 & 四月 & 初吉 & 甲寅 & 《集成》133-139 \\
\hline 颂鼎 & 晚期 & 三年 & 五月 & 既死霸 & 甲戌 & 《集成》2827-2829 \\
\hline 达㣱盖 & 中期 & 三年 & 五月 & 既生霸 & 壬寅 & 《商周》5661-5663 \\
\hline 癀賉 & 中期 & 四年 & 二月 & 既生霸 & 戊戌 & 《集成》4462-4463 \\
\hline 师酉盘 & 晚期 & 四年 & 三月 & 既生霸 & 甲戌 & 《续编》(2) 951 \\
\hline 敉伯车父鼎 & 晚期(3) & 四年 & 八月 & 初吉 & 丁亥 & 《集成》2697-2700 \\
\hline 敉季籃 & 晚期 & 四年 & 八月 & 初吉 & 丁亥 & 《集成》4126 \\
\hline 师酉鼎 & 中期 & 四祀 & 九月 & 初吉 & 丁亥 & 《商周》2475 \\
\hline 五祀卫鼎 & 中期 & 五祀 & 正月 & 初吉 & 庚戌 & 《集成》2832 \\
\hline 棟筬 & 晚期(4) & 五年 & 三月 & 初吉 & 庚寅 & 《商周》5336 \\
\hline 兮甲盘 & 晚期 & 五年 & 三月 & 既死霸 & 庚寅 & 《集成》10174 \\
\hline 五年师旅筬 & 晚期(5) & 五年 & 九月 & 既生霸 & 壬午 & 《集成》4216-4218 \\
\hline 宰兽笽 & 中期 & 六年 & 二月 & 初吉 & 甲戌 & 《商周》5376 \\
\hline 史伯硕父鼎 & 晚期 & 六年 & 八月 & 初吉 & 己巳 & 《商周》2424 \\
\hline 我笽 & 中期 & 七年 & 正月 & 初吉 & 甲申 & 《商周》5321 \\
\hline 七年师兑筬盖 & 晚期 & 七年 & 五月 & 初吉 & 甲寅 & 《商周》5302 \\
\hline 牧筬 & 中期 & 七年 & 十三月 & 既生霸 & 甲寅 & 《集成》4343 \\
\hline 齐生鲁方彝盖 & 中期 & 八年 & 十二月 & 初吉 & 丁亥 & 《集成》9896 \\
\hline 九年卫鼎 & 中期 & 九年 & 正月 & 既死霸 & 庚辰 & 《集成》2831 \\
\hline 畯筒 & 中期 & 十年 & 正月 & 初吉 & 甲寅 & 《商周》5386 \\
\hline 师骜筬 & 晚期 & 十一年 & 九月 & 初吉 & 丁亥 & 《集成》4324-4325 \\
\hline 太师虘筬 & 中期 & 十二年 & 正月 & 既望 & 甲午 & 《集成》4251-4252 \\
\hline 虢季子白盘 & 晚期 & 十二年 & 正月 & 初吉 & 丁亥 & 《商周》10173 \\
\hline 走筬 & 中期(6) & 十二年 & 三月 & 既望 & 庚寅 & 《商周》5329 \\
\hline 大筬盖 & 晚期 & 十二年 & 三月 & 既生霸 & 丁亥 & 《集成》4299 \\
\hline 无共筬 & 晚期 & 十三年 & 正月 & 初吉 & 壬寅 & 《集成》4225-4226 \\
\hline 望筬 & 中期 & 十三年 & 六月 & 初吉 & 戊戌 & 《集成》4272 \\
\hline 十三年痌壶 & 中期 & 十三年 & 九月 & 初吉 & 戊寅 & 《集成》9723-9724 \\
\hline 十五年大鼎 & 晚期 & 十五年 & 三月 & 既生霸(7) & 丁亥 & 《商周》2465-2467 \\
\hline 十五年趞曹鼎 & 中期 & 十五年 & 五月 & 既生霸 & 壬午 & 《集成》2784 \\
\hline 伯克壶 & 晚期 & 十六年 & 七月 & 既生霸(8) & 乙未 & 《集成》9725 \\
\hline 克鐳 & 晚期 & 十六年 & 九月 & 初吉 & 庚寅 & 《集成》209 \\
\hline
\end{tabular}

(1) 《商周》定为西周中期, 《集成》（器号 4277）定为西周晚期。

(2) 吴镇烽编著: 《商周青铜器铭文暨图像集成续编》, 上海: 上海古籍出版社, 2016 年。

(3) 《集成》定为西周晚期, 《商周》 (器号 2297-2300) 定为西周中期后段。

(4) 《商周》定为西周中期, 《集成》（器号 4285）定为西周晚期。

(5) 《集成》定为西周晚期, 《商周》（器号 5248-5250）定为西周中期后段。

(6) 《商周》定为西周中期, 《集成》（器号 4244）定为西周晚期。

(7) 铭文作 “既霸” , 本文理解为 “既生霸”。

８）铭文作 “既生雨”, 本文理解为 “既生霸”。 


\begin{tabular}{|c|c|c|c|c|c|c|}
\hline 器名 & 铜器断代 & 年祀 & 月序 & 记日用语 & 干支 & 著录 \\
\hline 士山盘 & 中期 & 十六年 & 九月 & 既生霸 & 甲申 & 《商周》14536 \\
\hline 此鼎 & 晚期 & 十七年 & 十二月 & 既生霸 & 乙卯 & 《集成》2821-2823 \\
\hline 善夫克盨 & 晚期 & 十八年 & 十二月 & 初吉 & 庚寅 & 《集成》4465 \\
\hline 吴虎鼎 & 晚期 & 十八年 & 十三月 & 既生霸 & 丙戌 & 《商周》2446 \\
\hline 赹鼎 & 晚期 & 十九年 & 四月 & 既望 & 辛卯 & 《集成》2815 \\
\hline 走马休盘 & 中期 & 廿年 & 正月 & 既望 & 甲戌 & 《集成》10170 \\
\hline 庚嬴鼎 & 中期(1) & 廿二年 & 四月 & 既望 & 已西 & 《商周》2379 \\
\hline 典筬 & 中期 & 廿四年(2) & 八月 & 既望 & 丁巳 & 《集粹》 (3) 第 76-77 页 \\
\hline 䚄篮 & 中期 & 廿四年 & 九月 & 既望 & 庚寅 & 《商周》5362 \\
\hline 小孟鼎 & 早期 & 廿五祀 & 八月 & 既望 & 甲申(4) & 《集成》2839 \\
\hline 番匊生壶 & 中期 & 廿六年 & 十月 & 初吉(5) & 已卯 & 《集成》9705 \\
\hline 倗叔壶 & 中期 & 廿六年 & 十月 & 初吉 & 已卯 & 《商周》12401 \\
\hline 伊籃 & 晚期 & 廿七年 & 正月 & 既望 & 丁亥 & 《集成》4287 \\
\hline 廿七年卫筬 & 中期 & 廿七年 & 三月 & 既生霸 & 戊戌 & 《集成》4256 \\
\hline 㱆笽 & 中期 & 廿八年 & 正月 & 既生霸 & 丁卯 & 《商周》5295 \\
\hline 弿盘 & 晚期 & 廿八年 & 五月 & 既望 & 庚寅 & 《集成》10172 \\
\hline 作册吴盉 & 中期 & 卅年 & 四月 & 既生霸 & 壬午 & 《商周》14797 \\
\hline 虎筬盖 & 中期 & 卅年 & 四月 & 初吉 & 甲戌 & 《商周》5399-5400 \\
\hline 槅做从鼎 & 晚期 & 卅一年 & 三月 & 初吉 & 王辰 & 《集成》2818 \\
\hline 大祝追鼎 & 晚期 & 卅二年 & 八月 & 初吉 & 辛巳 & 《商周》2396 \\
\hline 伯窅父䯶 & 晚期 & 卅三年 & 八月 & 既死霸(6) & 辛卯 & 《集成》4438-4439 \\
\hline 晋侯鮴钟 1 & 晚期 & 卅三年 & 正月 & 既生霸 & 戊午 & 《商周》15298-15313 \\
\hline 晋侯鮴钟 2 & 晚期 & 卅三年 & 二月 & 既望 & 癸卯 & 同上 \\
\hline 晋侯鮴钟 3 & 晚期 & 卅四年(7) & 二月 & 既死霸 & 壬寅 & 同上 \\
\hline 晋侯鮴钟 4 & 晚期 & 卅四年 & 六月 & 初吉 & 戊寅 & 同上 \\
\hline 鲜篮 & 中期 & 卅四祀 & 五月 & 既望 & 戊午 & 《集成》10166 \\
\hline 善夫山鼎 & 晚期 & 卅七年 & 正月 & 初吉 & 庚戌 & 《集成》2825 \\
\hline 曲二年佐鼎 & 晚期 & WII年 & 五月 & 既生霸 & 乙卯 & 《商周》2501-2502 \\
\hline 卅三年佐鼎 & 晚期 & WII年 & 六月 & 既生霸 & 丁亥 & 《商周》2503-2512 \\
\hline
\end{tabular}

\section{文献资料}

本文采用《汉书》引《尚书》历日以及《逸周书・世俘》篇历日作为推算的辅助材料。

(1) 《商周》定为西周中期, 《集成》（器号 2748）定为西周早期。

（2) 铭文作 “廿年又四年”，笔者理解为 “廿又四年”。

(3) 吕章申主编: 《近藏集粹: 中国国家博物馆新入藏文物》，北京：北京时代华文书局，2016 年。

(4) 铭文作 “唯八月既望，辰在甲申”，“甲申”二字原缺，据铭文中“雮若翌乙西” 补。笔者认为此句 “既 望”为甲申日的记日用语。

(5) 铭文作 “初”, 笔者理解为 “初吉”。

(6) 铭文作 “既死”，笔者理解为 “既死霸”。

(7) 铭文作 “二月既望癸卯”、“二月既死霸壬寅” , 按照干支次序, 癸卯在壬寅后一日。若不更改铭文, 则这 两条历日必不同年。本文认为“二月既死霸壬寅”在“二月既望癸卯”之来年。 
《尚书》的源流比较复杂, 今日所见的版本源自东晋梅赜所献的版本, 称梅献《尚书》, 共五十八篇。其中三十三篇与西汉伏生所传《今文尚书》略同，另外多出来的二十五篇称为晚 出《尚书》，学者多以为后世托伪之作。而成书于东汉的《汉书》在《律历志》当中也引用了 《尚书》的历日信息，应是刘歆所见西汉朝廷所藏中秘本《尚书》，或为孔壁古文《尚书》。 因此，本文仅采纳《汉书》所引《尚书》历日。

西晋出土的《汲冢竹书》虽然已经失传，但是后人从宋代以前的文献中辑录出引用的片 段, 称为古本《竹书纪年》。明代又出现了两卷本《竹书纪年》, 称今本《竹书纪年》。今本 《竹书纪年》的真伪有争议。十五年趞曹鼎铭文说 “唯十又五年五月既生霸壬午, 恭王在周新 宫” ，(1) 则恭王在位至少十五年; 而今本《竹书纪年》却记载恭王在位仅十二年。(2) 以此观 之, 今本《竹书纪年》的记载不可靠。因此，本文以古本《竹书纪年》为推算的参考。

近年从清华大学藏战国竹简（以下简称清华简）中整理出一本《系年》，其中记载了两周 之际史事，与《史记》颇有出入。鉴于出土佐鼎铭文历日与《史记》年表不能相合，本文采纳 《系年》作为推算的参考。

此外，传世先秦文献，如《国语》、《左传》等也记载了相关史事材料，本文亦作为推算 的参考资料。

表 2 文献历日信息一览表

\begin{tabular}{|c|c|c|c|c|c|}
\hline 篇名 & 年代 & 月序 & 记日用语 & 干支 & 出处 \\
\hline \multirow{3}{*}{ 《尚书・武成》 } & 克纣之年 & 一月 & 旁死霸 & 壬辰 & \multirow{3}{*}{ 《汉书》引《武成》(3) } \\
\hline & 同上 & 三月 & 既死霸 & 庚申 & \\
\hline & 同上 & 四月 & 既旁生霸 & 乙巳 & \\
\hline \multirow{2}{*}{ 《尚书・召诰》 } & \multirow{2}{*}{ 周公摄政七年 } & 二月 & 既望 & 庚寅 & \multirow{2}{*}{ 《汉书》引《召诰》 (4) } \\
\hline & & 三月 & 朏 & 丙午 & \\
\hline 《尚书·毕命》 & 康王十二年 & 六月 & 朏 & 庚午 & 《汉书》引《毕命》5 \\
\hline \multirow{3}{*}{ 《逸周书・世俘解》 } & 伐殷之年 & 一月 & 旁生魄 & 丙辰 & \multirow{3}{*}{ 《逸周书》 (6) } \\
\hline & 克纣之年 & 二月 & 既死魄 & 庚申 & \\
\hline & 同上 & 四月 & 既旁生魄 & 乙巳 & \\
\hline
\end{tabular}

(1) 相关著录详见表 1 。本文凡收录于表 1 的青铜器将不另行标明著录出处。

(2) 王国维: 《今本竹书纪年疏证》, 附于方诗铭、王修龄撰: 《古本竹书纪年辑证》, 上海: 上海古籍出版 社, 2005 年修订本, 第 252 页。

(3) 《汉书》卷 21《律历志下》, 北京: 中华书局, 1962 年点校本，第 4 册第 1015-1016 页。

(4) 《汉书》卷 21 《律历志下》, 第 4 册第 1016 页。

(5) 《汉书》卷 21 《律历志下》, 第 4 册第 1017 页。

(6) 《逸周书》卷 4 , 黄怀信、张惁镕、田旭东撰: 《逸周书汇校集注》, 上海: 上海古籍出版社, 2007 年修订 本, 上册第 $411-436$ 页。 


\section{结果与讨论}

\section{周王年代}

假设:

一、干支纪日至少从西周至今未曾中断。

二、西周历法以建子之月为岁首，或有前后一个月的浮动。

三、金文记日用语作如下理解: (1)

1. 既死霸的意思是月亮的亮面完全消失，始于晦日或朔日，终于朏日，大致在朔 日前后，共 2-3 天;

2. 既生霸的意思是月亮的亮面已经出现，朏日日暮时始见月牙，其次日为既生霸 之始，而既生霸终于望日，涵盖几乎整个上半月;

3. 既望的意思是满月已过，始于望日之后月面始亏，终于晦日，涵盖几乎整个下 半月;

4. 初吉不是月相, 可以为一个月内的任意一天，但是所系的日干支为虚拟干支， 不出现在当月（例如，“正月初吉丁亥”的意思是正月无丁亥日）;

四、西周历法每个月以既死霸为一月之始。

根据以上的推算假设，以表 1 所列的 81 条四要素俱全的金文历日为首要依据，再以文献资 料为辅助材料, 以鲁隐公三年 (平王崩年) 为推算起点, 可以推算得到上起文王受命元年、下 迄平王崩年的完整周王纪年，列于下表。

\section{表 3 周王年代方案}

\begin{tabular}{|c|c|c|c|c|c|c|c|c|c|}
\hline 公元前 & 王 王年 & 器名或篇名 & 年祀 & 月序 & 干支 & 记日用语 & 岁首 & 朔日 望日 & 备注 \\
\hline 1056 & 文 元 & & & & & & & & 受命改元 \\
\hline 1055 & 二 & & & & & & & & \\
\hline 1054 & 三 & & & & & & & & \\
\hline 1053 & 四 & & & & & & & & \\
\hline 1052 & 五 & & & & & & & & \\
\hline 1051 & 六 & & & & & & & & \\
\hline 1050 & 七 & & & & & & & & \\
\hline 1049 & 八 & & & & & & & & \\
\hline 1048 & 九 & & & & & & & & \\
\hline 1047 & 十 & & & & & & & & \\
\hline \multirow[t]{2}{*}{1046} & 武 十一 & 古本竹书纪年 & 十一年 & & & & & & 周始伐商 \\
\hline & & 世俘 & 伐殷之年 & 殷历一月 & 丙辰 & 旁生魄 & 亥 & 癸卯 丁巳 & 望前一日 \\
\hline 1045 & 十二 & & & & & & & & \\
\hline
\end{tabular}

(1) 王胜利先生在《西周历法的月首、年首和记日词语新探》 ( 《自然科学史研究》1990 年第 1 期) 一文中提出 了对记日用语的类似见解; 惟其以西周历法以朏之次日 (既生霸的第一天) 为月初, 以建丑之月为岁首。该文 亦指出初吉非月相，但是并未意识到初吉乃是虚拟历日。 


\begin{tabular}{|c|c|c|c|c|c|c|c|c|c|c|c|}
\hline 公元前 & 王 & 王年 & 器名或篇名 & 年祀 & 月序 & 干支 & 记日用语 & 岁首 & 朔日 & 望日 & 备注 \\
\hline \multirow{4}{*}{\multicolumn{2}{|c|}{1044}} & 十三 & 武成 & 克纣之年 & 殷历一月 & 壬辰 & 旁死霸 & 亥 & 辛卯 & 丙午 & 朔之次日 \\
\hline & & & 世俘 & 克纣之年 & 殷历二月 & 庚申 & 既死霸 & & 辛西 & 乙亥 & 朔前一日 \\
\hline & & & 武成 & 克纣之年 & 三月 & 庚申 & 既死霸 & & & & 同上 \\
\hline & & & 世俘及武成 & 克纣之年 & 四月 & 乙巳 & 既旁生霸 & & 庚寅 & 乙巳 & 望日 \\
\hline 1043 & & 十四 & & & & & & & & & \\
\hline 1042 & 成 & 元 & & & & & & & & & \\
\hline 1041 & & 二 & & & & & & & & & \\
\hline 1040 & & 三 & & & & & & & & & \\
\hline 1039 & & 四 & & & & & & & & & \\
\hline 1038 & & 五 & 祮尊 & 五祀 & 四月 & 丙戌 & & 子 & 乙西 & 庚子 & 朔之次日 \\
\hline 1037 & & 六 & & & & & & & & & \\
\hline \multirow{3}{*}{\multicolumn{2}{|c|}{1036}} & 七 & 召诰 & & 二月 & 庚寅 & 既望 & 丑 & 甲戌 & 戊子 & 望后二日 \\
\hline & & & 召诰 & & 三月 & 丙午 & 朏 & & 甲辰 & 戊午 & 朔后二日 \\
\hline & & & 洛诰 & 七年 & 十有二月 & 戊辰 & & & 己巳 & 甲申 & 朔前一日 \\
\hline 1035 & & 八 & & & & & & & & & \\
\hline 1034 & & 九 & & & & & & & & & \\
\hline 1033 & & + & & & & & & & & & \\
\hline 1032 & & 十一 & & & & & & & & & \\
\hline 1031 & & 十二 & & & & & & & & & \\
\hline 1030 & & 十三 & & & & & & & & & \\
\hline 1029 & & 十四 & & & & & & & & & \\
\hline 1028 & & 十五 & & & & & & & & & \\
\hline 1027 & & 十六 & & & & & & & & & \\
\hline 1026 & & 十七 & & & & & & & & & \\
\hline 1025 & & 十八 & & & & & & & & & \\
\hline 1024 & & 十九 & & & & & & & & & \\
\hline 1023 & & 二十 & & & & & & & & & \\
\hline 1022 & & 廿一 & & & & & & & & & \\
\hline 1021 & & 廿二 & & & & & & & & & \\
\hline 1020 & & 廿三 & & & & & & & & & \\
\hline 1019 & & 廿四 & & & & & & & & & \\
\hline 1018 & & 廿五 & & & & & & & & & \\
\hline 1017 & & 廿六 & & & & & & & & & \\
\hline 1016 & & 廿七 & & & & & & & & & \\
\hline 1015 & & 廿八 & 尧公篮 & 廿又八祀 & & & & & & & \\
\hline 1014 & & 廿九 & & & & & & & & & \\
\hline 1013 & & 三十 & & & & & & & & & \\
\hline 1012 & & 卅一 & & & & & & & & & \\
\hline 1011 & & 卅二 & 顾命 & 成王末年 & 四月 & 甲子 & & 子 & 戊申 & 癸亥 & 望之次日 \\
\hline 1010 & 康 & 元 & & & & & & & & & \\
\hline 1009 & & 二 & & & & & & & & & \\
\hline
\end{tabular}




\begin{tabular}{|c|c|c|c|c|c|c|c|c|c|c|c|}
\hline 公元前 & 王 王 & 王年 & 器名或篇名 & 年祀 & 月序 & 干支 & 记日用语 & 岁首 & 朔日 & 望日 & 备注 \\
\hline 1008 & 三 & $E$ & & & & & & & & & \\
\hline 1007 & 匹 & प् & & & & & & & & & \\
\hline 1006 & 五 & 五 & & & & & & & & & \\
\hline 1005 & 六 & i & & & & & & & & & \\
\hline 1004 & t & 七 & & & & & & & & & \\
\hline 1003 & 八 & 1 & & & & & & & & & \\
\hline 1002 & 九 & 乙 & & & & & & & & & \\
\hline 1001 & + & 十 & & & & & & & & & \\
\hline 1000 & & $1-$ & & & & & & & & & \\
\hline 999 & & $1 二$ & 毕命 & 十有二年 & 六月 & 庚午 & 朏 & 子 & 戊辰 & 辛巳 & 朔后二日 \\
\hline 998 & & 卜三 & & & & & & & & & \\
\hline 997 & & 十四 & & & & & & & & & \\
\hline 996 & & 十五 & & & & & & & & & \\
\hline 995 & & 卜六 & & & & & & & & & \\
\hline 994 & & 1七 & & & & & & & & & \\
\hline 993 & & 十八 & & & & & & & & & \\
\hline 992 & & 卜九 & 作册折方彝 & 十又九祀 & 五月 & 戊子 & & 丑 & 丁亥 & 辛丑 & 朔之次日 \\
\hline 991 & 昭 元 & 元 & & & & & & & & & \\
\hline 990 & 二 & E & & & & & & & & & \\
\hline 989 & 三 & E & & & & & & & & & \\
\hline 988 & 匹 & प् & & & & & & & & & \\
\hline 987 & 五 & 五 & & & & & & & & & \\
\hline 986 & 六 & i & & & & & & & & & \\
\hline 985 & t & $t$ & & & & & & & & & \\
\hline 984 & 八 & l & & & & & & & & & \\
\hline 983 & 九 & 乙 & & & & & & & & & \\
\hline 982 & + & 十 & & & & & & & & & \\
\hline 981 & & $十$ & & & & & & & & & \\
\hline 980 & & 卜三 & & & & & & & & & \\
\hline 979 & & 卜三 & & & & & & & & & \\
\hline 978 & & 卜四 & & & & & & & & & \\
\hline 977 & & 十五 & & & & & & & & & \\
\hline 976 & & 卜六 & & & & & & & & & \\
\hline 975 & & 卜七 & & & & & & & & & \\
\hline 974 & & 卜八 & & & & & & & & & \\
\hline 973 & & 十九 & & & & & & & & & \\
\hline 972 & & 二十 & & & & & & & & & \\
\hline 971 & & +一 & & & & & & & & & \\
\hline 970 & & 十二 & & & & & & & & & \\
\hline 969 & & 十三 & 大盂鼎 & 廿又三祀 & 九月 & & & & & & \\
\hline 968 & & 十四 & 典篮 & 廿年又四年 & 八月 & 丁巳 & 既望 & 子 & 丙申 & 辛亥 & 望后六日 \\
\hline
\end{tabular}




\begin{tabular}{|c|c|c|c|c|c|c|c|c|c|c|}
\hline 公元前 & 王 王年 & 器名或篇名 & 年祀 & 月序 & 干支 & 记日用语 & 岁首 & 朔日 & 望日 & 备注 \\
\hline & & 䚄筬 & 廿又四年 & 九月 & 庚寅 & 既望 & & 丙寅 & 辛巳 & 望后九日 \\
\hline 967 & 廿五 & 小孟鼎 & 廿又五祀 & 八月 & 甲申 & 既望 & 子 & 庚申 & 乙亥 & 望后九日 \\
\hline 966 & 廿六 & & & & & & & & & \\
\hline 965 & 廿七 & & & & & & & & & \\
\hline 964 & 廿八 & & & & & & & & & \\
\hline 963 & 廿九 & & & & & & & & & \\
\hline 962 & 三十 & & & & & & & & & \\
\hline 961 & 卅一 & & & & & & & & & \\
\hline 960 & 卅二 & & & & & & & & & \\
\hline 959 & 卅三 & & & & & & & & & \\
\hline 958 & 卅四 & 鲜筬 & 卅又四祀 & 五月 & 戊午 & 既望 & 丑 & 已亥 & 甲寅 & 望后四日 \\
\hline 957 & 穆 元 & 古本竹书纪年 & & & & & & & & 自周受命 100 年 \\
\hline 956 & 二 & & & & & & & & & \\
\hline 955 & 三 & & & & & & & & & \\
\hline 954 & 四 & & & & & & & & & \\
\hline 953 & 五 & & & & & & & & & \\
\hline 952 & 六 & & & & & & & & & \\
\hline 951 & 七 & & & & & & & & & \\
\hline 950 & 八 & & & & & & & & & \\
\hline 949 & 九 & 九年卫鼎 & 九年 & 正月 & 庚辰 & 既死霸 & 丑 & 已卯 & 癸巳 & 朔之次日 \\
\hline 948 & + & & & & & & & & & \\
\hline 947 & 十一 & & & & & & & & & \\
\hline 946 & 十二 & 走筬 & 十又二年 & 三月 & 庚寅 & 既望 & 子 & 辛西 & 丙子 & 望后十四日 \\
\hline 945 & 十三 & & & & & & & & & \\
\hline 944 & 十四 & & & & & & & & & \\
\hline 943 & 十五 & & & & & & & & & \\
\hline 942 & 十六 & & & & & & & & & \\
\hline 941 & 十七 & & & & & & & & & \\
\hline 940 & 十八 & & & & & & & & & \\
\hline 939 & 十九 & & & & & & & & & \\
\hline 938 & 二十 & 走马休盘 & 廿年 & 正月 & 甲戌 & 既望 & 子 & 乙巳 & 庚申 & 望后十四日 \\
\hline 937 & 廿一 & & & & & & & & & \\
\hline 936 & 廿二 & 庚嬴鼎 & 廿又二年 & 四月 & 己西 & 既望 & 子 & 壬辰 & 丁未 & 望后二日 \\
\hline 935 & 廿三 & 倗伯爯筬 & 廿又三年 & & 戊戌 & 初吉 & & & & \\
\hline 934 & 廿四 & & & & & & & & & \\
\hline 933 & 廿五 & & & & & & & & & \\
\hline \multirow[t]{2}{*}{932} & 廿六 & 番番生壶 & 廿又六年 & 十月 & 已卯 & 初吉 & 亥 & 丙申 & 辛亥 & 当月无己卯日 \\
\hline & & 倗叔壶 & 廿又六年 & 十月 & 已卯 & 初吉 & & & & 同上 \\
\hline 931 & 廿七 & 廿七年卫篮 & 廿又七年 & 三月 & 戊戌 & 既生霸 & 子 & 甲午 & 戊申 & 朔后四日 \\
\hline 930 & 廿八 & 虏篮 & 廿又八年 & 正月 & 丁卯 & 既生霸 & 丑 & 已未 & 癸西 & 朔后八日 \\
\hline 929 & 廿九 & & & & & & & & & \\
\hline
\end{tabular}




\begin{tabular}{|c|c|c|c|c|c|c|c|c|c|c|}
\hline 公元前 王 & 王 王年 & 器名或篇名 & 年祀 & 月序 & 干支 & 记日用语 & 岁首 & 朔日 & 望日 & 备注 \\
\hline \multirow[t]{2}{*}{928} & 三十 & 虎筬盖 & 卅年 & 四月 & 甲戌 & 初吉 & 子 & 丙子 & 辛卯 & 当月无甲戌日 \\
\hline & & 作册吴盉 & 卅年 & 四月 & 壬午 & 既生霸 & & & & 朔后六日 \\
\hline 927 & 卅一 & & & & & & & & & \\
\hline 926 & 井二 & & & & & & & & & \\
\hline 925 & 井三 & & & & & & & & & \\
\hline 924 & 卅四 & 师奎父鼎 & & 六月 & 庚寅 & 既生霸 & 子 & 壬午 & 丁酉 & 朔后八日 \\
\hline 923 & 井五 & & & & & & & & & \\
\hline 922 & 㘫六 & 师瘦筬盖 & & 二月 & 戊寅 & 初吉 & 子 & 癸卯 & 丁巳 & 当月无戊寅日 \\
\hline 921 & 井七 & & & & & & & & & \\
\hline 920 & 卅八 & & & & & & & & & \\
\hline 919 & 卅九 & 长白盉 & & 三月 & 丁亥 & 初吉 & 丑 & 甲寅 & 己巳 & 当月无丁亥日 \\
\hline 918 & 四十 & & & & & & & & & \\
\hline 917 恭 & 恭 元 & 蔡篮 & 元年 & & 丁亥 & 既望 & & & & \\
\hline \multirow[t]{2}{*}{916} & 二 & 豆闭筬 & & 二月 & 戊寅 & 既生霸 & 子 & 丁卯 & 壬午 & 朔后十一日 \\
\hline & & 王臣筬 & 二年 & 三月 & 庚寅 & 初吉 & & 丁西 & 壬子 & 当月无庚寅日 \\
\hline 915 & 三 & 車卫盉 & 三年 & 三月 & 壬寅 & 既生霸 & 亥 & 壬辰 & 丙午 & 朔后十日 \\
\hline 914 & 四 & & & & & & & & & \\
\hline 913 & 五 & 五祀卫鼎 & 五祀 & 正月 & 庚戌 & 初吉 & 子 & 辛巳 & 乙未 & 当月无庚戌日 \\
\hline 912 & 六 & & & & & & & & & \\
\hline 911 & 七 & 七年趞曹鼎 & 七年 & 十月 & & 既生霸 & & & & \\
\hline 910 & 八 & & & & & & & & & \\
\hline 909 & 九 & 拜伯筬 & 九年 & 九月 & 甲寅 & & 亥 & 甲寅 & 戊辰 & 朔日 \\
\hline 908 & + & & & & & & & & & \\
\hline 907 & 十一 & & & & & & & & & \\
\hline \multirow[t]{2}{*}{906} & 十二 & 太师虘篮 & 十又二年 & 正月 & 甲午 & 既望 & 亥 & 辛未 & 乙西 & 望后九日 \\
\hline & & 永盂 & 十又二年 & & 丁卯 & 初吉 & & & & \\
\hline \multirow[t]{2}{*}{905} & 十三 & 望篮 & 十又三年 & 六月 & 戊戌 & 初吉 & 子 & 壬戌 & 丁丑 & 当月无戊戊日 \\
\hline & & 十三年㾶壶 & 十又三年 & 九月 & 戊寅 & 初吉 & & 庚寅 & 乙巳 & 当月无戊寅日 \\
\hline 904 & 十四 & & & & & & & & & \\
\hline 903 & 十五 & 十五年趞曹鼎 & 十又五年 & 五月 & 壬午 & 既生霸 & 丑 & 庚辰 & 甲午 & 朔后二日 \\
\hline 902 & 十六 & 士山盘 & 十又六年 & 九月 & 甲申 & 既生霸 & 子 & 壬申 & 丁亥 & 朔后十二日 \\
\hline 901 & 十七 & 訇篮 & 十又七祀 & & & & & & & \\
\hline 900 & 十八 & & & & & & & & & \\
\hline \multirow[t]{2}{*}{899 競 } & 壸 元 & 师西篮 & 元年 & 正月 & & & 子 & & & \\
\hline & & 师虎篮 & 元年 & 六月 & 甲戌 & 既望 & & 丙辰 & 辛未 & 望后三日 \\
\hline 898 & 二 & 吴方彝盖 & 二祀 & 二月 & 丁亥 & 初吉 & 子 & 癸丑 & 戊辰 & 当月无丁亥日 \\
\hline 897 & 三 & 师遽筬盖 & 三祀 & 四月 & 辛西 & 既生霸 & 子 & 癸卯 & 辛西 & 望日 \\
\hline 896 & 四 & 师西盘 & 四年 & 三月 & 甲戌 & 既生霸 & 亥 & 壬申 & 丙戌 & 朔后二日 \\
\hline 895 & 五 & & & & & & & & & \\
\hline 894 & 六 & 宰兽篮 & 六年 & 二月 & 甲戌 & 初吉 & 子 & 庚寅 & 甲辰 & 当月无甲戌日 \\
\hline 893 & 七 & 牧筬 & 七年 & 十又三月 & 甲寅 & 既生霸 & 子 & 戊申 & 甲子 & 朔后六日 \\
\hline
\end{tabular}




\begin{tabular}{|c|c|c|c|c|c|c|c|c|c|c|c|}
\hline 公元前 & 王 & 王年 & 器名或篇名 & 年祀 & 月序 & 干支 & 记日用语 & 岁首 & 朔日 & 望日 & 备注 \\
\hline 892 & & 八 & 齐生鲁方彝盖 & 八年 & 十又二月 & 丁亥 & 初吉 & 丑 & 癸卯 & 戊午 & 当月无丁亥日 \\
\hline 891 & & 九 & & & & & & & & & \\
\hline 890 & & 十 & 畯笽 & 十年 & 正月 & 甲寅 & 初吉 & 子 & 丁卯 & 壬午 & 当月无甲寅日 \\
\hline 889 & & 十一 & & & & & & & & & \\
\hline 888 & & 十二 & 舀鼎 2 & & 四月 & 丁酉 & 既生霸 & 亥 & 甲申 & 已亥 & 朔后十三日 \\
\hline 887 & 孝 & 元 & 舀鼎 1 & 元年 & 六月 & 乙亥 & 既望 & 子 & 丁未 & 壬戌 & 望后十三日 \\
\hline 886 & & 二 & 趩觯 & 二年 & 三月 & 乙卯 & 初吉 & 子 & 癸西 & 丁亥 & 当月无乙卯日 \\
\hline \multirow[t]{3}{*}{885} & & 三 & 师晨鼎 & 三年 & 三月 & 甲戌 & 初吉 & 子 & 丁酉 & 辛亥 & 当月无甲戌日 \\
\hline & & & 师俞篮盖 & 三年 & 三月 & 甲戌 & 初吉 & & & & \\
\hline & & & 达䁅盖 & 三年 & 五月 & 壬寅 & 既生霸 & & 丙申 & 庚戌 & 朔后六日 \\
\hline \multirow[t]{2}{*}{884} & & 四 & 瘨䁅 & 四年 & 二月 & 戊戌 & 既生霸 & 丑 & 辛卯 & 丙午 & 朔后七日 \\
\hline & & & 师酉鼎 & 四祀 & 九月 & 丁亥 & 初吉 & & 戊子 & 癸卯 & 当月无丁亥日 \\
\hline 883 & & 五 & 棟篮 & 五年 & 三月 & 庚寅 & 初吉 & 子 & 乙卯 & 庚午 & 当月无庚寅日 \\
\hline 882 & & 六 & & & & & & & & & \\
\hline 881 & 夷 & 元 & 师言篮 & 元年 & 二月 & 庚寅 & 既望 & 子 & 甲戊 & 己丑 & 望之次日 \\
\hline 880 & & 二 & & & & & & & & & \\
\hline 879 & & 三 & & & & & & & & & \\
\hline 878 & & 四 & & & & & & & & & \\
\hline 877 & & 五 & & & & & & & & & \\
\hline 876 & & 六 & 辅师骜筬 & & 九月 & 甲寅 & 既生霸 & 丑 & 辛丑 & 丙辰 & 朔后十三日 \\
\hline 875 & & 七 & 我篮 & 七年 & 正月 & 甲申 & 初吉 & 子 & 已亥 & 乙卯 & 当月无甲申日 \\
\hline 874 & & 八 & & & & & & & & & \\
\hline 873 & & 九 & & & & & & & & & \\
\hline 872 & & + & & & & & & & & & \\
\hline 871 & & 十一 & & & & & & & & & \\
\hline \multirow[t]{5}{*}{870} & 厉 & 元 & 元年师䞄篮 & 元年 & 四月 & 甲寅 & 既生霸 & 丑 & 已亥 & 甲寅 & 望日 \\
\hline & & & 元年师兑篮 & 元年 & 五月 & 甲寅 & 初吉 & & 戊辰 & 甲申 & 当月无甲寅日 \\
\hline & & & 伯吕父徂 & 元年 & 六月 & 庚戌 & 既生霸 & & 戊戊 & 癸丑 & 朔后十二日 \\
\hline & & & 郑季昷 & 元年 & 六月 & 丁亥 & 初吉 & & & & 当月无丁亥日 \\
\hline & & & 师顥筬 & 元年 & 九月 & 丁亥 & 既望 & & 丙寅 & 辛巳 & 望后六日 \\
\hline 869 & & 二 & & & & & & & & & \\
\hline 868 & & 三 & 三年师兑篮 & 三年 & 二月 & 丁亥 & 初吉 & 子 & 己丑 & 癸印 & 当月无丁亥日 \\
\hline 867 & & 四 & & & & & & & & & \\
\hline \multirow{3}{*}{\multicolumn{2}{|c|}{866}} & 五 & 五年琱生篮 & 五年 & 正月 & 已丑 & & 子 & 丁丑 & 壬辰 & 朔后十二日 \\
\hline & & & 五年师旅篮 & 五年 & 九月 & 壬午 & 既生霸 & & 甲戌 & 戊子 & 朔后八日 \\
\hline & & & 五年琱生尊 & 五年 & 九月 & 初吉 & & & & & \\
\hline \multirow[t]{2}{*}{865} & & 六 & 六年琱生筬 & 六年 & 四月 & 甲子 & & 子 & 庚子 & 乙卯 & 望后九日 \\
\hline & & & 史伯硕父鼎 & 六年 & 八月 & 己巳 & 初吉 & & 已亥 & 癸丑 & 当月无己巳日 \\
\hline 864 & & 七 & 七年师兑筬盖 & 七年 & 五月 & 甲寅 & 初吉 & 亥 & 甲子 & 己卯 & 当月无甲寅日 \\
\hline 863 & & 八 & & & & & & & & & \\
\hline 862 & & 九 & & & & & & & & & \\
\hline
\end{tabular}




\begin{tabular}{|c|c|c|c|c|c|c|c|c|c|c|}
\hline 公元前 王 & 王 王年 & 器名或篇名 & 年祀 & 月序 & 干支 & 记日用语 & 岁首 & 朔日 & 望日 & 备注 \\
\hline 861 & 十 & & & & & & & & & \\
\hline 860 & 十一 & 师謷筬 & 十又一年 & 九月 & 丁亥 & 初吉 & 子 & 戊戌 & 甲寅 & 当月无丁亥日 \\
\hline 859 & 十二 & 㝬筬 & 十又二祀 & & & & & & & \\
\hline 858 & 十三 & 无貪篮 & 十又三年 & 正月 & 壬寅 & 初吉 & 子 & 辛西 & 丙子 & 当月无壬寅日 \\
\hline 857 & 十四 & & & & & & & & & \\
\hline 856 & 十五 & 十五年大鼎 & 十又五年 & 三月 & 丁亥 & 既生霸 & 子 & 戊寅 & 癸巳 & 朔后九日 \\
\hline 855 & 十六 & 克铺 & 十又六年 & 九月 & 庚寅 & 初吉 & 丑 & 已亥 & 癸丑 & 当月无庚寅日 \\
\hline 854 & 十七 & & & & & & & & & \\
\hline 853 & 十八 & 善夫克盨 & 十又八年 & 十又二月 & 庚寅 & 初吉 & 子 & 丁巳 & 辛未 & 当月无庚寅日 \\
\hline 852 & 十九 & & & & & & & & & \\
\hline 851 & 二十 & & & & & & & & & \\
\hline 850 & 廿一 & & & & & & & & & \\
\hline 849 & 廿二 & & & & & & & & & \\
\hline 848 & 廿三 & 小克鼎 & 廿又三年 & 九月 & & & & & & \\
\hline 847 & 廿四 & & & & & & & & & \\
\hline 846 & 廿五 & 雬比盄 & 廿又五年 & 七月 & $\square \square$ & & & & & \\
\hline 845 & 廿六 & & & & & & & & & \\
\hline 844 & 廿七 & 伊籃 & 廿又七年 & 正月 & 丁亥 & 既望 & 子 & 庚午 & 甲申 & 望后三日 \\
\hline 843 & 廿八 & & & & & & & & & \\
\hline 842 & 廿九 & & & & & & & & & \\
\hline 841 & 三十 & & & & & & & & & \\
\hline 840 & 卅一 & 需比筬盖 & 卅又一年 & 三月 & 壬辰 & 初吉 & 丑 & 丙午 & 庚申 & 当月无壬辰日 \\
\hline 839 & 卅二 & & & & & & & & & \\
\hline 838 & 册三 & 伯窅父湎 & 卅又三年 & 八月 & 辛卯 & 既死霸 & 丑 & 辛卯 & 乙巳 & 朔日 \\
\hline 837 & 卅四 & & & & & & & & & \\
\hline 836 宣 & 宣 元 & 师舀筬 & 元年 & 正月 & 丁亥 & 初吉 & 子 & 癸丑 & 戊辰 & 当月无丁亥日 \\
\hline 835 & 二 & 咽篮 & 二年 & 正月 & 丁亥 & 初吉 & 子 & 戊申 & 壬戌 & 当月无丁亥日 \\
\hline 834 & 三 & 柞钟 & 三年 & 四月 & 甲寅 & 初吉 & 亥 & 辛未 & 乙酉 & 当月无甲寅日 \\
\hline \multirow[t]{2}{*}{833} & 四 & 敉伯车父鼎 & 四年 & 八月 & 丁亥 & 初吉 & 子 & 壬辰 & 丁未 & 当月无丁亥日 \\
\hline & & 敉季笽 & 四年 & 八月 & 丁亥 & 初吉 & & & & 同上 \\
\hline 832 & 五 & 兮甲盘 & 五年 & 三月 & 庚寅 & 既死霸 & 丑 & 已丑 & 癸卯 & 朔之次日 \\
\hline 831 & 六 & & & & & & & & & \\
\hline 830 & 七 & & & & & & & & & \\
\hline 829 & 八 & & & & & & & & & \\
\hline 828 & 九 & & & & & & & & & \\
\hline 827 & + & & & & & & & & & \\
\hline 826 & 十一 & & & & & & & & & \\
\hline 825 & 十二 & 大籃盖 & 十又二年 & 三月 & 丁亥 & 既生霸 & 丑 & 戊寅 & 癸巳 & 朔后九日 \\
\hline 824 & 十三 & & & & & & & & & \\
\hline 823 & 十四 & & & & & & & & & \\
\hline 822 & 十五 & & & & & & & & & \\
\hline
\end{tabular}




\begin{tabular}{|c|c|c|c|c|c|c|c|c|c|c|c|}
\hline 公元前 & 王 王 & 王年 & 器名或篇名 & 年祀 & 月序 & 干支 & 记日用语 & 岁首 & 朔日 & 望日 & 备注 \\
\hline 821 & & 十六 & 伯克壶 & 十又六年 & 七月 & 乙未 & 既生霸 & 丑 & 癸未 & 丁酉 & 朔后十二日 \\
\hline 820 & & 十七 & 此鼎 & 十又七年 & 十又二月 & 乙卯 & 既生霸 & 子 & 乙巳 & 庚申 & 朔后十日 \\
\hline 819 & & 十八 & 吴虎鼎 & 十又八年 & 十又三月 & 丙戌 & 既生霸 & 子 & 己巳 & 甲申 & 望后二日 \\
\hline 818 & & 十九 & 赹鼎 & 十又九年 & 四月 & 辛卯 & 既望 & 子 & 丁卯 & 壬午 & 望后九日 \\
\hline 817 & & 二十 & & & & & & & & & \\
\hline 816 & & 廿一 & & & & & & & & & \\
\hline 815 & & 廿二 & & & & & & & & & \\
\hline 814 & & 廿三 & & & & & & & & & \\
\hline 813 & & 廿四 & & & & & & & & & \\
\hline 812 & & 廿五 & & & & & & & & & \\
\hline 811 & & 廿六 & & & & & & & & & \\
\hline 810 & & 廿七 & & & & & & & & & \\
\hline 809 & & 廿八 & 蓑盘 & 廿又八年 & 五月 & 庚寅 & 既望 & 子 & 甲戊 & 庚寅 & 望日 \\
\hline 808 & & 廿九 & & & & & & & & & \\
\hline 807 & & 三十 & & & & & & & & & \\
\hline 806 & & 册一 & & & & & & & & & \\
\hline 805 & & 卅二 & 大祝追鼎 & 卅又二年 & 八月 & 辛巳 & 初吉 & 子 & 庚戌 & 乙丑 & 当月无辛巳日 \\
\hline \multirow[t]{2}{*}{804} & & 卅三 & 晋侯鮴钟 1 & 卅又三年 & 正月 & 戊午 & 既生霸 & 子 & 丁未 & 壬戌 & 朔后十一日 \\
\hline & & & 晋侯鮴钟 2 & & 二月 & 癸卯 & 既望 & & 丁丑 & 壬辰 & 望后十一日 \\
\hline \multirow[t]{2}{*}{803} & & 卅四 & 晋侯鮴钟 3 & & 二月 & 壬寅 & 既死霸 & 丑 & 辛丑 & 丙辰 & 朔之次日 \\
\hline & & & 晋侯鮴钟 4 & & 六月 & 戊寅 & 初吉 & & 已亥 & 癸丑 & 当月无戊寅日 \\
\hline 802 & & 卅五 & & & & & & & & & \\
\hline 801 & & 卅六 & & & & & & & & & \\
\hline 800 & & 卅七 & 善夫山鼎 & 卅又七年 & 正月 & 庚戌 & 初吉 & 子 & 乙卯 & 己巳 & 当月无庚戌日 \\
\hline 799 & & 卅八 & & & & & & & & & \\
\hline 798 & & 卅九 & & & & & & & & & \\
\hline 797 & & 四十 & & & & & & & & & \\
\hline 796 & & m- & & & & & & & & & \\
\hline 795 & & 曲二 & WII 二年佐鼎 & 州又二年 & 五月 & 乙卯 & 既生霸 & 丑 & 癸丑 & 丁卯 & 朔后二日 \\
\hline 794 & & 曲三 & 冊三年佐鼎 & 州又三年 & 六月 & 丁亥 & 既生霸 & 丑 & 丁丑 & 辛印 & 朔后十日 \\
\hline 793 & & 冊四 & & & & & & & & & \\
\hline 792 & & 冊五 & & & & & & & & & \\
\hline 791 & & 冊六 & & & & & & & & & \\
\hline 790 & 幽 元 & 元 & 古本竹书纪年 & & & & & & & & 自武王 257 年 \\
\hline 789 & & 二 & & & & & & & & & \\
\hline 788 & & 三 & 颂鼎 & 三年 & 五月 & 甲戌 & 既死霸 & 子 & 癸西 & 丁亥 & 朔之次日 \\
\hline 787 & & 四 & & & & & & & & & \\
\hline 786 & & 五 & & & & & & & & & \\
\hline 785 & & 六 & & & & & & & & & \\
\hline 784 & & 七 & & & & & & & & & \\
\hline 783 & & 八 & & & & & & & & & \\
\hline
\end{tabular}




\begin{tabular}{|c|c|c|c|c|c|c|c|c|c|c|}
\hline 公元前 & 王 & 王年 & 器名或篇名 & 年祀 & 月序 & 干支 & 记日用语 & 岁首 & 朔日 望日 & 备注 \\
\hline 782 & & 九 & & & & & & & & \\
\hline 781 & & + & & & & & & & & \\
\hline 780 & & 十一 & & & & & & & & \\
\hline 779 & 携 & 元 & 逆钟 & 元年 & 三月 & 庚申 & 既生霸 & 子 & 壬子 丙寅 & 朔后八日 \\
\hline 778 & & 二 & & & & & & & & \\
\hline 777 & & 三 & & & & & & & & \\
\hline 776 & & 四 & & & & & & & & \\
\hline 775 & & 五 & & & & & & & & \\
\hline 774 & & 六 & & & & & & & & \\
\hline 773 & & 七 & & & & & & & & \\
\hline 772 & & 八 & 清华简系年 & 周亡王九年 & & & & & & 晋文侯立平王 \\
\hline 771 & & 九 & & & & & & & & \\
\hline 770 & & + & 清华简系年 & 平王三年 & & & & & & 东迁至成周 \\
\hline 769 & & $+一$ & & & & & & & & \\
\hline 768 & & 十二 & 虢季子白盘 & 十又二年 & 正月 & 丁亥 & 初吉 & 子 & 戊申 甲子 & 当月无丁亥日 \\
\hline 767 & & 十三 & & & & & & & & \\
\hline 766 & & 十四 & & & & & & & & \\
\hline 765 & & 十五 & & & & & & & & \\
\hline 764 & & 十六 & & & & & & & & \\
\hline 763 & & 十七 & & & & & & & & \\
\hline 762 & & 十八 & & & & & & & & \\
\hline 761 & & 十九 & & & & & & & & \\
\hline 760 & & 二十 & & & & & & & & \\
\hline 759 & & 廿一 & 清华简系年 & 立廿又一年 & & & & & & 晋文侯杀携王 \\
\hline 758 & 平 & 十五 & & & & & & & & \\
\hline 757 & & 十六 & & & & & & & & \\
\hline 756 & & 十七 & & & & & & & & \\
\hline 755 & & 十八 & & & & & & & & \\
\hline 754 & & 十九 & & & & & & & & \\
\hline 753 & & 二十 & & & & & & & & \\
\hline 752 & & 廿一 & & & & & & & & \\
\hline 751 & & 廿二 & & & & & & & & \\
\hline 750 & & 廿三 & & & & & & & & \\
\hline 749 & & 廿四 & & & & & & & & \\
\hline 748 & & 廿五 & & & & & & & & \\
\hline 747 & & 廿六 & & & & & & & & \\
\hline 746 & & 廿七 & & & & & & & & \\
\hline 745 & & 廿八 & & & & & & & & \\
\hline 744 & & 廿九 & & & & & & & & \\
\hline 743 & & 三十 & & & & & & & & \\
\hline 742 & & 卅一 & & & & & & & & \\
\hline
\end{tabular}




\begin{tabular}{|c|c|c|c|c|c|c|c|c|c|c|}
\hline 公元前 & 王 王年 & 器名或篇名 & 年祀 & 月序 & 干支 & 记日用语 & 岁首 & 朔日 & 望日 & 备注 \\
\hline 741 & 卅二 & & & & & & & & & \\
\hline 740 & 卅三 & & & & & & & & & \\
\hline 739 & 卅四 & & & & & & & & & \\
\hline 738 & 卅五 & & & & & & & & & \\
\hline 737 & 卅六 & & & & & & & & & \\
\hline 736 & 卅七 & & & & & & & & & \\
\hline 735 & 卅八 & & & & & & & & & \\
\hline 734 & 卅九 & & & & & & & & & \\
\hline 733 & 四十 & & & & & & & & & \\
\hline 732 & WII- & & & & & & & & & \\
\hline 731 & InI & & & & & & & & & \\
\hline 730 & WIE & & & & & & & & & \\
\hline 729 & 州四 & & & & & & & & & \\
\hline 728 & 州五 & & & & & & & & & \\
\hline 727 & 冊六 & & & & & & & & & \\
\hline 726 & 州七 & & & & & & & & & \\
\hline 725 & 曲八 & & & & & & & & & \\
\hline 724 & 州九 & & & & & & & & & \\
\hline 723 & 五十 & & & & & & & & & \\
\hline 722 & 五一 & & & & & & & & & 鲁隐公元年 \\
\hline 721 & 五二 & & & & & & & & & \\
\hline 720 & 五三 & 春秋左氏传 & 隐公三年 & 王二月 & 己巳 & & 丑 & 己巳 & 甲申 & 日食; 推算起点 \\
\hline
\end{tabular}

上表可以在一字不改的情况下容纳表 1 所列全部四要素俱全的金文历日共 81 条, 另可容纳 四要素未足的金文历日（器名以斜体字表示） 22 条, 合计 103 条。这是笔者所知的可容纳金文 历日最多的周王年代方案。此外，还可容纳文献中的历日信息 12 条，同样一字不改。

除了武王即位未改元之外，本文推算得到文王至夷王九位周王的元年，校改厉王、宣王、 幽王与平王元年，增补传世文献失载的携王元年。由此补足有周一代的纪年。

此外, 还可推定周代一些重大事件的年代: 武王克纣之年相当于公元前 1044 年; 周公归政 之年相当于公元前 1036 年; 偹父迁晋在成王二十八年, 相当于公元前 1015 年; 共和行政未单 独纪年，应纳入厉王世 (下文将详述推理过程 ), 则国人暴动在厉王二十年, 相当于公元前 851 年, 共和始行政在其明年 (相当于公元前 850 年, 而非公元前 841 年 ) ; 犬戎杀幽王在幽王十 一年，相当于公元前 780 年; 平王东迁之年仍相当于公元前 770 年，但是为平王三年，而非平 王元年; 晋文侯杀携王在携王二十一年，相当于公元前 759 年。

校改厉王、宣王、幽王元年, 并调整记日用语的理解方式之后, 以往安排年代比较困难的 晚期器金文历日, 都可以得到合理的安排。如, 以往伊笽的年代安排比较困难, 而按照本文的 推算，可排入厉王世。又如，晋侯鮴钟铭文中，有 “二月既望癸卯” 及 “二月既死霸壬寅” 两 条历日, 因干支次序壬寅恰在癸卯之前, 以往多认为有误刻。笔者将二月既死霸壬寅置于二月 
既望之来年, 则晋侯鮴钟可与佐鼎一并排入宣王世。将初吉历日理解为虚拟历日 ( 将初吉理解 为虚拟历日的推理过程将在下文探讨 ) 之后，也可将元年师兄笽与三年师兑笽纳入同一王世。

鲜篮铭文纪年高达三十四年, 且铭文记录时王 “禘于昭王” , 以往多以为穆王器。然而, 其历日却无法与其它推在穆王世的金文历日（如廿七年卫笽、作册吴盉铭文历日 ) 相容。本年 表将鲜篮置于昭王末年，其时昭王已崩，时王为穆王，但是尚未改元。

学者多认为晋侯鮴钟的器主晋侯鮴即是文献中的晋献侯籍。笔者将晋侯鮴钟排入宣王世, 虽然与《史记》年表中晋献侯的在位年代不符，但是却与出土信息并不矛盾。晋侯鮴钟出自山 西曲沃北赵晋侯墓地 M8, 对墓中采集的树枝木炭样本做碳十四测年并用树轮校正曲线校正之 后，所得年代范围在公元前 828 年至公元前 797 年之间（95.4\%置信区间）。(1) 本文将晋侯魝钟 的年代定在宣王三十三年、三十四年，相当于公元前 804-803 年，符合碳十四测年结果。

\section{金文历日的合天情况}

四要素俱全的 81 条历日中，既死霸历日 5 条，均在朔日前后一日的范围内。既望历日 16 条，除衰盘铭文历日在望日之外，其余历日均在望日之后。其中，走篮、走马休盘与舀鼎铭文 历日在当月晦日。既生霸历日 24 条，除吴虎鼎铭文在望后二日之外，其余历日均在朔后二日至 望日之间。其中, 师遽笽盖以及元年师族篮铭文历日在望日。总体而论, 除了吴虎鼎铭文历日 月相误差达到两日之外，其余历日的月相误差均不超过一日。这足以证明本文对既生霸、既望 及既死霸的理解是合理的。

从金文历日合天的情况来看，既死霸、既生霸、既望的分界点偶有浮动。如，晦日时而属 既死霸, 时而属既望; 望日有时属既生霸, 有时属既望。这暗示西周历法应当仍处于观象授时 的阶段。从实践的角度思考, 月相的判断, 不仅需要考虑月亮光面占整个月面的比率 (下文简 称盈满率）, 还得考虑其它会影响肉眼观察的因素。如，月升、月落与日出、日没的关系（即 使盈满率已经可见，但是当日日没时分月亮才升出，则当天仍属既死霸，次日才属既生霸）, 以及月亮和太阳在天空中的视差角度 ( 即使月亮的盈满率已可见, 且月亮与太阳均已升起, 要 是月亮与太阳视差角度太小，肉眼仍看不见月亮）。此外，观察地的大气条件也有可能影响对 月相的判断（如，阳光在大气中的折射有可能使月亮的形状产生轻微变形，从而影响判断）。

既死霸应是以晦日或朔日能否见到残月作为判断依据。在朔日前后，月出、月没与日出、 日没的时间比较接近。在合朔以前, 月亮会比太阳稍早一点升出地平线。如果晦日月出时间比 日出时间提早较多, 且日、月的视差角度较大, 即使残月的盈满率较低, 仍有可能被经过训练 的专业人员观察到。如果晦日清晨见到残月，则当日仍属既望; 如果没有见到残月，则属既死 霸。

既生霸的判断当是以月牙初现为依据。然而, 朔日刚过，月出、月没均稍微落后于日出、 日没。因此, 新生的月牙只能在日落之际看到。同样地, 能否见到新月牙, 也受到日落、月落 的时间差以及日、月的视差角度的影响，可能会有前后一天的浮动。如果朔之次日黄昏观察到 新月牙，那么其次日属既生霸，否则其次日仍属既死霸。

(1) 仇士华、张长寿: 《晋侯墓地 18 的碳十四年代测定和晋侯鮴钟》, 《考古》1999 年第 5 期。 
通过以上的分析，可以有此推论：如果月相术语是通过肉眼观象来判定的，那么晦日有可 能属既望，也有可能属既死霸；朔日一定属既死霸；朔之次日，无论当天黄昏是否见到新月 牙，也一定属既死霸；既生霸最早不能早于朔后二日。这也符合本文的推算结果。

既望有可能是以月面是否出现亏缺为判断依据。在望日前后，月升大约在日落之际，同样 月没大概在日出之际。观察月相只能在日落之后或日出之前。从实践的角度考虑，有两种可 能：一是在前一日晚上已见到月亮圆满, 即达到了 “望” ，那么第二天就是既望; 另一种可能 是在日出之际、月没之前观察到月面亏缺，则当日为既望，否则当日仍属既生霸。

若采用这种方法判定 “既望” ，与既死霸和既生霸的判定方法相比，月相的辨识难度比较 高: 判断夜空中残月牙或新月牙之有无是比较明确的。判断月亮是否开始亏缺则相对较难以辨 认，而且月球亮面的形状还有可能受到大气折射的影响而产生变形。这有可能导致既生霸和既 望的分界点距满月有相对较大的误差。

既望还有可能是以是否见到日、月隔空相望作为判断的依据，这就回归到“望”的本义。 在满月以前, 月升比日落稍早一点; 在满月以后, 月落比日出稍迟一点。如果某天观察到了日 月东西相望, 则当日就是望, 仍属既生霸, 而其次日属既望。某天能否观察到日月相望, 会受 到月升和日落（或者月落和日出）的时间差的影响。事实上，满月时，日月正相对，不应同时 出现在地平线以上。因此，采用此法判定既望，那么既生霸与既望的分界点与满月会有一定的 误差。此外, 能否看到日月相望, 还有可能受到当地地形的影响: 如果处在山谷之中, 那么日 月虽然在地平线以上，但是受到地形的遮蔽，因而也不可见。这也有可能导致误差。

\section{初吉历日是虚拟历日}

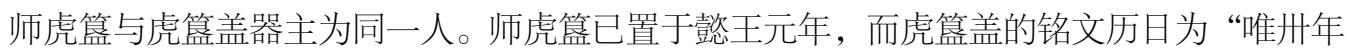
四月初吉甲戌” ，只能排入穆王世。同在穆王三十年的还有作册吴盉，其铭文历日为 “唯卅年 四月既生霸壬午”。当年子正四月丙子朔（公元前 928 年 3 月 13 日 17:58:19 合朔），壬午在朔 后六日（3 月 19 日），而甲戌却在朔前二日（3 月 11 日）。也就是说，穆王三十年四月的第一 天无论是朔日还是朏日，当月都没有甲戌日。笔者由此怀疑，初吉历日有可能是虚拟历日。

由于两周金文所用干支以 “丁亥” 最多，有学者曾提出 “初吉丁亥” 可以是虚拟历日，(1) 其引用的例证之一为《仪礼・少牢馈食礼》的筮日之辞： “孝孙某，来日丁亥，用荐岁事于皇 祖伯某，以某妃配某氏，尚飨!”此句郑玄注引《禘于太庙礼》曰: “日用丁亥，不得丁亥， 则已亥、辛亥亦用之，无则苟有亥焉可也。” (2) 按照郑玄的解释，虽然禘于太庙礼应当用丁亥 日, 但是需要通过卜筮选定吉日, 而吉日未必是丁亥日, 只要是亥日即可。郑玄意以为《少牢 馈食礼》筮日之辞中的 “来日丁亥” 也是同理, 此处 “丁亥” 只是虚拟历日, 未必是礼仪当日 的实际干支。因此，有学者提出，“初吉丁亥”可能是表示这个虚拟的丁亥日的专门术语。

(1) 庞朴: 《“五月丙午” 与 “正月丁亥”》, 《文物》1979 年第 6 期; 李学勤: 《〈夏小正〉新证》, 王元化 主编: 《古文献从论》, 上海: 上海远东出版社, 1996 年, 第212-224 页。

(2) 《仪礼注疏》卷 47 , 《十三经注疏》, 第 11 册第 1038 页。 
笔者注意到，《仪礼・少牢馈食礼》日“日用丁、已”， 1 《礼记・郊特牲》日“日用 甲” ，(2) 郑玄引《禘于太庙礼》曰 “日用丁亥”，说明不同的礼仪所用的干支不同。又，《礼 记・曲礼上》说卜筮用日之法：“外事以刚日，内事以柔日。” 孔颖达解之曰：“甲、丙、 戊、庚、壬五奇为刚也”，“乙、丁、己、辛、癸五偶为柔也”。(3) 这说明在卜筮吉日的时候 很重视干支。这样看来，因卜筮吉日而需要书写虚拟历日的情形应该不仅限于丁亥。于是笔者 猜想，西周金文当中所有的初吉历日可能都是虚拟历日。

将初吉理解为虚拟历日, 就可以化解每自备(4)铭文的历日冲突。緐占铭文曰: “唯九月初吉 癸丑, 公肜祀。雮旬又一日辛亥, 公禘肜辛公祀”。依文意, “公” 在九月初吉癸丑那天肜祀 之后，过了 11 天又在辛亥日肜祀。可是检验干支次序，发现辛亥日反在癸丑日之前。如果将初 吉历日理解为虚拟历日，则九月初吉并非癸丑日。当天的实际干支可由辛亥日回溯旬又一日求 得（此处用内含计数法，将首尾之日均计入 11 日之数），为辛丑，与癸丑同为丑日。这与禘于 太庙礼 “日用丁亥，不得丁亥……苟有亥焉可也” 的情形类似，是支持初吉历日为虚拟历日的 实证。

据此，笔者猜想，初吉历日不仅 “可以” 是虚拟历日，而且 “必须” 是虚拟历日。这可以 通过安排初吉历日的年代来检验。(5) 以初吉历日为虚拟历日，那么虎篮盖历日就正好可以置于 穆王三十年：当年四月无甲戌日，合于初吉。按照这种理解初吉的方式，可合理安排全部初吉 历日。在安排初吉历日时, 主要依据铭文的人物关联。在有多解的情况下则优先选取建正相合 的年份。

\section{推算结果与铜器断代、人物关联相符}

除了与月相符合之外, 诸器的王世安排也和由铜器形制、纹饰与铭文字体风格等信息推断 的大致时代相符。以本文的推算结果观之，西周早期与中期大致以昭、穆之际为界，中期与晚 期大致以孝、夷之世为界。另外，本文的推算结果也符合铭文中的人物关联，如表 4 所示。

\section{表 4 金文人物关联一览表}

\begin{tabular}{|c|c|c|c|c|}
\hline \multirow{2}{*}{ 人物 } & \multirow{2}{*}{ 所见器铭 } & \multicolumn{2}{|c|}{ 年代 (公元前) } & \multirow{2}{*}{ 跨度 } \\
\hline & & 初见 & 终见 & \\
\hline 表卫 & 九年卫鼎、廿七年卫笽、表卫盉、五祀卫鼎 & 949 & 913 & 37 \\
\hline 司马邢伯䚄 & 䚄筬、走筬、师夲父鼎、师㾔筬盖 & 968 & 922 & 47 \\
\hline 邢伯 & 长甶盉、豆闭篾、五祀卫鼎、七年趞曹鼎、永盂、师虎篮 & 919 & 899 & 21 \\
\hline 邢叔 & 舀鼎、趩觯、达盄盖 & 887 & 885 & 3 \\
\hline 益公 & 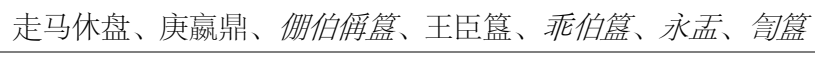 & 938 & 901 & 38 \\
\hline
\end{tabular}

(1) 《仪礼注疏》卷 47, 《十三经注疏》, 第 11 册第 1037 页。

(2) 《礼记正义》卷 25, 《十三经注疏》, 第 13 册第 917 页。

(3) 《礼记正义》卷 2, 《十三经注疏》, 第 12 册第 103-104 页。

(4) 《集成》器号 5430 。

(5) 任何科学的假说, 必须能够被证伪。如果假设初吉历日 “可以” 是虚拟历日, 当其所系干支在当月出现时, 初吉历日不是虚拟历日, 当其所系干支不在当月出现时, 初吉历日为虚拟历日, 那么不会有任何一年无法容纳 初吉历日，这个假设就无法被证伪。而如果假设初吉历日 “必须” 是虚拟历日，限定其所系干支不能出现在当 月, 那么有可能出现某年无法容纳初吉历日的情形, 就可以将此假设证伪。 


\begin{tabular}{|c|c|c|c|c|}
\hline \multirow{2}{*}{ 人物 } & \multirow{2}{*}{ 所见器铭 } & \multicolumn{2}{|c|}{ 年代 (公元前) } & \multirow{2}{*}{ 跨度 } \\
\hline & & 初见 & 终见 & \\
\hline 作册吴、内史吴 & 作册吴盉、师㾔篾盖、师虎笽、吴方彝盖、牧篮、 & 928 & 893 & 36 \\
\hline 师虎 & 虎籃盖、师虎篮 & 928 & 899 & 30 \\
\hline 趞曹 & 七年趞曹鼎、十五年趞曹鼎 & 911 & 903 & 9 \\
\hline 奎父 & 师奎父鼎、永盂 & 924 & 906 & 19 \\
\hline 师戏 & 虎筬盖、豆闭袆 & 928 & 916 & 13 \\
\hline 史年 & 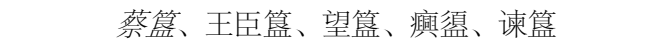 & 917 & 883 & 45 \\
\hline 师氥 & 氮筬、师詹篮 & 901 & 881 & 21 \\
\hline 师慗 & 辅师骜篾、师骜篮 & 876 & 860 & 17 \\
\hline 俗父 & 五祀卫鼎、永盎、师晨鼎、师酉鼎 & 913 & 884 & 30 \\
\hline 荣伯 & 永盂、宰兽筬、师訇筬、辅师慗袆 & 906 & 876 & 31 \\
\hline 师晨 & 太师盧笽、师晨鼎 & 906 & 885 & 12 \\
\hline 宰曶 & 蔡筬、太师覰笽 & 917 & 906 & 12 \\
\hline 师酉 & 师西篮、师西盘、师酉鼎 & 899 & 884 & 16 \\
\hline 㾶 & 十三年减壸、减盂 & 905 & 884 & 22 \\
\hline 史墙 & 十三年减壶、 (1) 师西墭、师西盘 & 905 & 896 & 12 \\
\hline 趩 & 趩觯、达馌盖 & 886 & 885 & 2 \\
\hline 司马共 & 师晨鼎、师俞筬盖、减盄、棟笽 & 885 & 883 & 3 \\
\hline 琱生 & 五年琱生篮、五年琱生尊、六年琱生篮、师骜篮 & 866 & 860 & 7 \\
\hline 棆父 & 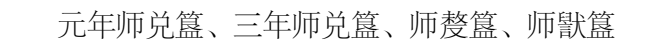 & 870 & 836 & 35 \\
\hline 大 & 十五年大鼎、大篮盖 & 856 & 825 & 32 \\
\hline 克 & 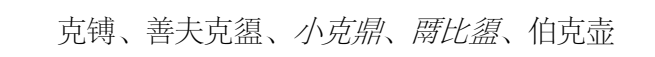 & 855 & 821 & 35 \\
\hline 师兑 & 元年师兑䇝、三年师兑笽、七年师兑筒盖 & 870 & 864 & 7 \\
\hline 师㫏 & 元年师族筤、五年师旅笽 & 870 & 866 & 5 \\
\hline 霹比 & 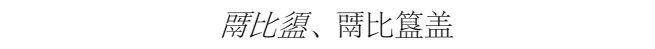 & 846 & 840 & 7 \\
\hline
\end{tabular}

如表 4 所示，年代跨度 40 年以上者有两例，30-40 年之间者十例，20-30 年之间者三例， 10-20 年之间者六例，10 年以下者八例。均在人的正常生理寿命范围内。

\section{推算结果与古代天象相符}

除了《世俘》、《武成》记载的月相之外，传世文献与出土金文中还有其它关于武王伐殷 时天象的记载。《国语・周语下》载: “昔武王伐殷, 岁在敦火, 月在天汕, 日在析木之津, 辰在斗柄, 星在天㒶。” (2)《淮南子・兵略训》载: “武王伐纣, 东面而迎岁”。(3) 利篮(4) 铭文 “岁鼎”，解读为木星上中天。

江晓原先生、钮卫星先生完全忽略出土材料, 仅由上述天象记录 (舍弃《国语》所载 “岁 在敦火” 的天象)，以及《世俘》、《武成》所载历日干支 (不对 “既死霸” 等记日用语下定

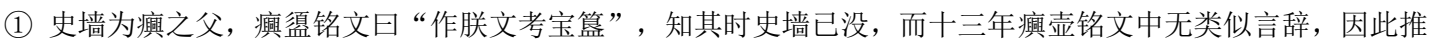
测瘨作此壸时史墙尚健在。史墙另作有史墙盘, 据其铭文知在恭王世。但是因铭文没有年代信息故未收入表 3 。

(2) 徐元诰撰: 《国语集解》, 北京: 中华书局, 2002 年, 第 123-124页。

(3) 何宁撰: 《淮南子集释》, 北京: 中华书局, 1998 年, 下册第 1065 页。

(4) 《集成》器号 4131 。 
义），推得武王克纣的日期在公元前 1044 年 1 月 9 日。 (1) 由于江、钮未对 “既死霸” 一词作任 何解读, 其推算结论之一即是 “既死霸” 只能解作晦或朔不见月之日。夏商周断代工程采用类 似的材料与方法，据《国语》“岁在敦火”，将武王克纣之年置于公元前 1046 年。(2)

由本文的推算结果可知，上述据《国语》天象所求得的年代，均能符合 “武王伐殷” : 公 元前 1046 年为周受命十一年，当年周始伐殷。(3) 公元前 1044 年为周受命十三年，当年 1 月 9 日武王克纣。这也符合文献所载观兵孟津的事迹。(4) 由此可见《国语》所载武王伐殷的天象可 信，惟 “武王伐殷” 当理解为自受命十一年初次伐殷至受命十三年克纣历时两年的整个过程， 而非一场战役。

古本《竹书纪年》载 “懿王元年, 天再旦于郑” ，夏商周断代工程认为这记录的是一次日 出前的日食, 并据此推断懿王元年在公元前 899 年, 日食发生在当年 4 月 21 日。(5) 这个结论也 与本文的推算结果相符。

由文献记载的天象推算历史纪年，需要面对最大的质疑是文献本身的可靠性。本文则从金 文历日入手，先推得金文记日用语最合理的理解方式，并据此推算、安排昭王以下诸王年代， 再据文献中的年代或干支月相信息推算史事纪年。用不同的材料与方法，却能得到一致的结 果, 极大地提高了结论的可靠性。结合本文与前贤的推算结果, 文献中的天象记录也可以得到 出土材料的支撑。

\section{推算结果与古本《竹书纪年》所载周王年代信息相符}

从受命元年 (公元前 1056 年) 到穆王元年 (公元前 957 年)，正好一百年，符合古本《竹 书纪年》“自周受命至穆王百年” 的记载。(6) 周公归政在公元前 1036 年，成王即政在公元前 1035 年，而昭王元年在公元前 991 年。只要成王亲政后战争的时间没有持续超过四年，也可符 合古本《竹书纪年》 “成、康之际，天下安宁，刑措四十余年不用” 的记载。(7) 由古本《竹书 纪年》的记载推知昭王在位至少十九年、穆王在位至少三十七年、夷王在位至少七年, 皆与推 算结果相符。

本文的推算结果也可以解决西周积年的问题。古本《竹书纪年》中，关于西周积年有三种 说法：《史记》集解引《汲冢竹书》曰，“自武王灭殷，以至于幽王，二百五十七年”，《通 鉴外纪》引《汲冢竹书》则有两种不同的说法，分别作 “自武王至幽王二百五十七年” 及 “西 周二百五十七年”。(8) 从本文的推算结果来看，《汲冢竹书》的原文疑当作 “自武王伐殷，以

(1) 江晓原, 钮卫星: 《以天文学方法重现武王伐纣之年代及日程表》, 《科学》1999 年第 5 期。

(2) 夏商周断代工程专家组: 《夏商周断代工程 1996 2000 年阶段成果概要》，《文物》2000 年第 12 期。

(3) 《新唐书・历志》引《竹书》: “十一年庚寅, 周始伐商。” 见方诗铭、王修龄撰: 《古本竹书纪年辑 证》，第 42 页。此句 “庚寅” 为一行推算所得，非《竹书纪年》原文。

(4) 《史记 - 周本纪》: “武王上祭于毕。东观兵, 至于盟津 ……是时, 诸侯不期而会盟津者八百诸侯。诸侯皆 曰: ‘纣可伐矣。’ 武王曰: ‘女未知天命, 未可也。’ 乃还师归。居二年, 闻纣昏乱暴虐滋甚……是武王 遍告诸侯曰: “殷有重罪, 不可以不毕伐。' 乃遵文王……以东伐纣。” 见《史记》卷 4 《周本纪》, 第 1 册第 156-157 页。

(5) 夏商周断代工程专家组: 《夏商周断代工程 1996 2 2000 年阶段成果概要》, 《文物》 2000 年第 12 期。

(6) 方诗铭、王修龄撰: 《古本竹书纪年辑证》, 第 47 页。

(7) 方诗铭、王修龄撰: 《古本竹书纪年辑证》, 第 45 页。

(8) 方诗铭、王修龄撰: 《古本竹书纪年辑证》, 第 64 页。 
至于幽王, 二百五十七年”。从受命十一年 (公元前 1046 年) 武王初次伐殷, 至幽王元年 (公 元前 790 年）, 恰好二百五十七年。引者误以武王伐殷为武王克纣, 故《史记》集解引作 “武 王灭殷” ，而《通鉴外纪》误以 “武王伐殷” 为西周始年, 又误以为二百五十七年通算至幽王 末年。若以西周始于武王克纣 ( 公元前 1044 年)，终于犬戎灭幽王 (公元前 780 年)，则西周 积二百六十五年。

\section{推算结果与清华简《系年》所载两周之际年代信息相符}

清华简《系年》所载两周之际史事与《史记》有较大差异，现引述如下： (1)

周幽王取妻于西申，生平王，王或取褒人之女，是褒姒，生伯盘。褒姒嬖于王，王与伯盘 逐平王, 平王走西申。幽王起师, 围平王于西申, 申人弗界, 缯人乃降西戎, 以攻幽王, 幽王 及伯盘乃灭，周乃亡。邦君、诸正乃立幽王之弟余臣于虢，是携惠王。立廿又一年，晋文侯仇 乃杀惠王于虢。周亡王九年, 邦君诸侯焉始不朝于周, 晋文侯乃逆平王于少鄂, 立之于京师。 三年，乃东徙，止于成周，晋人焉始启于京师，郑武公亦正东方之诸侯。

按照《系年》的记载，平王并没有在幽王死后马上即位，而是在 “周亡王九年” 由晋文侯 迎立。对 “周亡王” 的解读有多种意见。鉴于古本《竹书纪年》中有 “周二王并立” 的说法, (2) “周亡王” 不应理解为携王死后没有周王, 而当解作 “宗周无王”。3 从《系年》对幽王弟 余臣所用的 “携惠王” 的称呼来看, 余臣乃是 “携” 之惠王, 正如周幽王是 “周” 之幽王。相 应地，犬戎攻灭幽王，宗周无王，故曰 “周乃亡”、“周亡王”。在宗周无王的第九年，晋文 侯迎立平王，当年为平王元年。平王三年东迁至成周，“周” 又有王了，但是此 “周” 非彼

“周” : 幽王以上诸王在宗周, 在西, 故称西周; 平王以下诸王在成周, 在东, 故称东周。而 按照《系年》的观念，虽然余臣是周王族成员，但因未居于周地，故不在 “周王” 之数。按照 上述解读《系年》的方式来安排两周之际年代，可得表 5 所示结果。

表 5 两周之际年代对照

\begin{tabular}{|c|c|c|c|c|}
\hline \multirow{2}{*}{ 公元前 } & \multirow{2}{*}{ 《史记》年表 } & \multicolumn{3}{|c|}{ 本文据《系年》校补 } \\
\hline & & 周王纪年 & “周亡王” & 携王纪年 \\
\hline 790 & 宣王卅八 & 幽王元年 & & \\
\hline 789 & 井九 & 二年 & & \\
\hline 788 & 四十 & 三年 & & \\
\hline 787 & WI- & 四年 & & \\
\hline 786 & 州二 & 五年 & & \\
\hline 785 & WIE & 六年 & & \\
\hline 784 & 冊四 & 七年 & & \\
\hline 783 & 州五 & 八年 & & \\
\hline 782 & 冊六 & 九年 & & \\
\hline
\end{tabular}

(1) 李学勤主编: 《清华大学藏战国竹简（武）》, 上海: 中西书局, 2011 年, 下册第 138 页。

(2) 见方诗铭、王修龄撰: 《古本竹书纪年辑证》，第 63-64 页。

(3) 王伟: 《清华简〈系年〉 “周亡王九年” 及其相关问题研究》, 《中原文化研究》2015 年第 6 期。 


\begin{tabular}{rr|r|r|r}
\hline \multirow{2}{*}{ 公元前 } & \multirow{2}{*}{ 《史记》年表 } & \multicolumn{3}{|c}{ 本文据《系年》校补 } \\
& & 周王纪年 & “周亡王” & 携王纪年 \\
\hline 781 & 幽王元年 & 十年 & & \\
780 & 二年 & 十一 & 初年 & \\
779 & 三年 & & 二年 & 惠王元年 \\
778 & 四年 & & 三年 & 二年 \\
777 & 五年 & & 四年 & 三年 \\
776 & 六年 & & 五年 & 四年 \\
775 & 七年 & & 六年 & 五年 \\
774 & 八年 & & 七年 & 六年 \\
773 & 九年 & & 八年 & 七年 \\
772 & 十年 & 平王元年 & 九年 & 八年 \\
771 & 十一 & 二年 & & 九年 \\
770 & 平王元年 & 三年 & & 十年 \\
769 & 二年 & 四年 & & 十一 \\
768 & 三年 & 五年 & & 十二 \\
767 & 四年 & 六年 & & 十三 \\
766 & 五年 & 七年 & & 十四 \\
\hline 765 & 六年 & 八年 & & 十五 \\
\hline
\end{tabular}

由于 “周亡王” 并非王年, 不存在逾年改元的问题, 所以幽王死之当年即为周亡王初年。 那么周亡王九年相当于公元前 772 年, 当年晋文侯迎立平王, 是平王元年。平王三年东迁, 恰 当公元前 770 年, 与《史记》的记载一致。

从上表的总结可以看出，在幽王十一年和平王元年之间，周王纪年有七年的空白。从《史 记》失载携王的现象来推测, 司马迁没有见到携王相关的史料, 因此不知道周王纪年曾中断。 这应该是太史公在编列共和以前年代时遇到困难的重要原因，也可解释《史记》年表的错误。

古本《竹书纪年》以及清华简《系年》的记载可以与出土金文相互印证，说明这些文献是 可靠的史料。

\section{共和行政应纳入厉王纪年}

本文的推算结果显示共和行政并未单独纪年。那么，共和行政应该纳入厉王纪年还是宣王 纪年?

《史记》与《系年》均记载共和行政十四年。(1) 若共和行政纳入宣王纪年, 则共和行政末 年在宣王十四年。那么宣王元年至十四年之间的铜器均作于共和期间。其中, 兮甲盘置于宣王 五年，其铭文记录了兮甲追随时王征伐猃狁的事迹（“兮甲从王折首执讯”）。《史记》与

(1) 《史记 - 周本纪》: “共和十四年, 厉王死于疾。” 《《史记》卷 4 , 第 1 册第 182 页; 清华简《系年》: “……共伯和立。十又四年, 厉王生宣王, 宣王即位, 共伯和归于宗。” 见李学勤主编: 《清华大学藏战国竹 简（武）》，下册第 136 页。 
《系年》均记载共和时期厉王在炨，(1) 则此王不是厉王。古本《竹书纪年》虽记载共伯和 “行 天子政” , (2) 却并没有共伯和称王的记载。《史记》则认为共和行政指的是周、召二相共和行 政之称，乃是无王时期。(3) 如果共伯和没有称王，那么时王就只能是宣王了。

一般认为共和时期因为宣王年幼, 故由大臣行王政。而如果将共和行政纳入宣王纪年, 那 么五年时宣王已能够领兵打仗了, 不合常理。由此, 笔者认为共和行政应当纳入厉王纪年。如 果这样安排, 共和十四年为厉王末年, 反推共和初年在厉王二十一年, 即公元前 850 年。这意 味着伊篮和伯窅父䁅作于共和时期。伊篮铭文曰 “王在周康宫” ，伯窅父矗铭文曰“王在成 周”，此王当为宣王。从铭文推测，当时宣王在成周，则共伯和或在宗周。

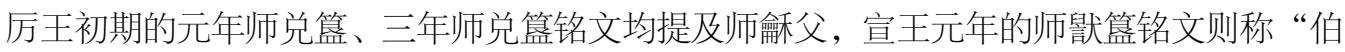
㖮父若曰”，显示伯掄父地位尊贵。结合《系年》所载 “宣王即位，共伯和归于宗” 推断，(4) 师㖮父、伯掄父有可能就是文献中的共伯和。

\section{鲁公年代校补}

《史记・十二诸侯年表》当是司马迁综合整理多方材料的成果。现知《史记》年表当中鲁 隐公三年 (相当于公元前 720 年) 以前的周王年代有误，那公对应时期的其余诸侯的年代恐怕 也有误。因《史记》记载了除初代鲁公伯禽以外历代鲁公的在位时间, 而现又推定了历代周王 以及伯禽的元年，笔者尝试据此校补鲁公年代。

笔者注意到，据《鲁世家》记载，真公十四年厉王奔哭、二十九年宣王即位，孝公二十五 年犬戎杀幽王。(5) 然而，在《十二诸侯年表》当中，伯御的十一年被纳入孝公纪年，就导致虽 然犬戎杀幽王发生在孝公即位的第二十五年，当年却是孝公三十六年。(6)

笔者怀疑，司马迁之所以这样安排，很可能是因为鲁国史料明言犬戎杀幽王在孝公二十五 年, 但又出现了孝公三十年以上的纪年。由于司马迁不知道周王纪年曾中断, 因此据鲁公积年 推算的厉王奔颔年与据周王积年推算的结果有矛盾。为了化解矛盾, 司马迁便将伯御的十一年 纳入孝公纪年, 并更动平王元年。这意味着, 《史记》只调整了孝公的纪年, 而其余鲁公的在 位时长无误。

按照这个思路校补鲁公年代，仍以厉王奔㫐在真公十四年、则宣王即位仍在二十九年。真 公在位三十年, 则武公元年相当于公元前 834 年; 武公在位十年 (从《史记》年表)，则懿公 元年相当于公元前 824 年; 懿公在位九年, 则伯御元年相当于公元前 815 年; 伯御在位十一 年, 则孝公元年相当于前 804 年。(7) 而本文推算犬戎杀幽王相当于公元前 780 年, 恰为孝公二

(1) 《史记・周本纪》: “厉王出奔于踟。” 《《史记》卷 4, 第 1 册第 181 页; 清华简《系年》: “厉王大虐 于周, 卿士、诸正、万民弗忍于厥心, 乃归厉王于彘。” 见李学勤主编: 《清华大学藏战国竹简（弐）》, 下 册第 136 页。

(2) 方诗铭、王修龄撰: 《古本竹书纪年辑证》，第 58 页。

(3) 《史记・周本纪》: “召公、周公二相行政, 号曰 ‘共和”。” 《史记》卷 4, 第 1 册第 182 页。

(4) 李学勤主编: 《清华大学藏战国竹简》, 下册第 136 页。

(5) 《史记》卷 33 《鲁周公世家》，第 5 册第 1838-1840 页。

(6) 《史记》卷 14 《十二诸侯年表》，第 2 册第 655-665 页。

(7) 以上鲁公在位年数据《史记》卷 14 《十二诸侯年表》，第 2 册第 $644-665$ 页。 
十五年, 与《鲁世家》的记载一致。如果维持惠公元年 (相当于公元前 768 年) 不变, 则孝公 在位三十六年, 仅比《史记》年表所载缩短两年而已。以上推算结果总结于下表:

表 6 两周之际鲁公年代校正方案

\begin{tabular}{|c|c|c|c|c|c|c|}
\hline \multirow{2}{*}{$\begin{array}{c}\text { 年代 } \\
\text { ( 公元前) }\end{array}$} & \multicolumn{3}{|c|}{ 《史记》年表 } & \multicolumn{3}{|c|}{ 本文校正 } \\
\hline & 周王纪年 & 鲁公纪年 & 备注 & 周王纪年 & 鲁公纪年 & 备注 \\
\hline 851 & & 真公五年 & & 厉王二十 & 真公十四 & 厉王奔氮 \\
\hline 850 & & 六年 & & 廿一 & 十五 & 共和行政 \\
\hline 849 & & 七年 & & 廿二 & 十六 & \\
\hline 848 & & 八年 & & 廿三 & 十七 & \\
\hline 847 & & 九年 & & 廿四 & 十八 & \\
\hline 846 & & 十年 & & 廿五 & 十九 & \\
\hline 845 & & 十一 & & 廿六 & 二十 & \\
\hline 844 & & 十二 & & 廿七 & 廿一 & \\
\hline 843 & & 十三 & & 廿八 & 廿二 & \\
\hline 842 & & 十四 & 厉王奔昆 & 廿九 & 廿三 & \\
\hline 841 & 共和元年 & 十五 & 共和行政 & 三十 & 廿四 & \\
\hline 840 & 二年 & 十六 & & 卅一 & 廿五 & \\
\hline 839 & 三年 & 十七 & & 卅二 & 廿六 & \\
\hline 838 & 四年 & 十八 & & 卅三 & 廿七 & \\
\hline 837 & 五年 & 十九 & & 井四 & 廿八 & \\
\hline 836 & 六年 & 二十 & & 宣王元年 & 廿九 & 宣王即位 \\
\hline 835 & 七年 & 廿一 & & 二年 & 三十 & \\
\hline 834 & 八年 & 廿二 & & 三年 & 武公元年 & \\
\hline 833 & 九年 & 廿三 & & 四年 & 二年 & \\
\hline 832 & 十年 & 廿四 & & 五年 & 三年 & \\
\hline 831 & 十一 & 廿五 & & 六年 & 四年 & \\
\hline 830 & 十二 & 廿六 & & 七年 & 五年 & \\
\hline 829 & 十三 & 廿七 & & 八年 & 六年 & \\
\hline 828 & 十四 & 廿八 & & 九年 & 七年 & \\
\hline 827 & 宣王元年 & 廿九 & 宣王即位 & 十年 & 八年 & \\
\hline 826 & 二年 & 三十 & & 十一 & 九年 & \\
\hline 825 & 三年 & 武公元年 & & 十二 & 十年 & \\
\hline 824 & 四年 & 二年 & & 十三 & 懿公元年 & \\
\hline 823 & 五年 & 三年 & & 十四 & 二年 & \\
\hline 822 & 六年 & 四年 & & 十五 & 三年 & \\
\hline 821 & 七年 & 五年 & & 十六 & 四年 & \\
\hline 820 & 八年 & 六年 & & 十七 & 五年 & \\
\hline 819 & 九年 & 七年 & & 十八 & 六年 & \\
\hline 818 & 十年 & 八年 & & 十九 & 七年 & \\
\hline 817 & 十一 & 九年 & & 二十 & 八年 & \\
\hline 816 & 十二 & 十年 & & 廿一 & 九年 & \\
\hline 815 & 十三 & 懿公元年 & & 廿二 & 伯御元年 & \\
\hline 814 & 十四 & 二年 & & 廿三 & 二年 & \\
\hline
\end{tabular}




\begin{tabular}{|c|c|c|c|c|c|c|}
\hline 年代 & \multicolumn{3}{|c|}{ 《史记》年表 } & \multicolumn{3}{|c|}{ 本文校正 } \\
\hline (公元前) & 周王纪年 & 鲁公纪年 & 备注 & 周王纪年 & 鲁公纪年 & 备注 \\
\hline 813 & 十五 & 三年 & & 中四 & 三年 & \\
\hline 812 & 十六 & 四年 & & 廿五 & 四年 & \\
\hline 811 & 十七 & 五年 & & 廿六 & 五年 & \\
\hline 810 & 十八 & 六年 & & 廿七 & 六年 & \\
\hline 809 & 十九 & 七年 & & 廿八 & 七年 & \\
\hline 808 & 二十 & 八年 & & 廿九 & 八年 & \\
\hline 807 & 廿一 & 九年 & & 三十 & 九年 & \\
\hline 806 & 廿二 & 伯御元年 & & 卅一 & 十年 & \\
\hline 805 & 廿三 & 二年 & & 卅二 & 十一 & 宣王杀伯御 \\
\hline 804 & 廿四 & 三年 & & 卅三 & 孝公元年 & \\
\hline 803 & 廿五 & 四年 & & 册四 & 二年 & \\
\hline 802 & 廿六 & 五年 & & 卅五 & 三年 & \\
\hline 801 & 廿七 & 六年 & & 卅六 & 四年 & \\
\hline 800 & 廿八 & 七年 & & 卅七 & 五年 & \\
\hline 799 & 廿九 & 八年 & & 卅八 & 六年 & \\
\hline 798 & 三十 & 九年 & & 卅九 & 七年 & \\
\hline 797 & 卅一 & 十年 & & 四十 & 八年 & \\
\hline 796 & 卅二 & 十一 & 宣王杀伯御 & mIt- & 九年 & \\
\hline 795 & 卅三 & 孝公十二 & 孝公未改元 & m配 & 十年 & \\
\hline 794 & 卅四 & 十三 & & 曲三 & 十一 & \\
\hline 793 & 卅五 & 十四 & & 冊四 & 十二 & \\
\hline 792 & 卅六 & 十五 & & 冊五 & 十三 & \\
\hline 791 & 卅七 & 十六 & & 冊六 & 十四 & \\
\hline 790 & 卅八 & 十七 & & 幽王元年 & 十五 & \\
\hline 789 & 卅九 & 十八 & & 二年 & 十六 & \\
\hline 788 & 四十 & 十九 & & 三年 & 十七 & \\
\hline 787 & WII- & 二十 & & 四年 & 十八 & \\
\hline 786 & mI 二 & 廿一 & & 五年 & 十九 & \\
\hline 785 & 冊三 & 廿二 & & 六年 & 二十 & \\
\hline 784 & 冊四 & 廿三 & & 七年 & 廿一 & \\
\hline 783 & 州五 & 廿四 & & 八年 & 廿二 & \\
\hline 782 & 冊六 & 廿五 & & 九年 & 廿三 & \\
\hline 781 & 幽王元年 & 廿六 & & 十年 & 廿四 & \\
\hline 780 & 二年 & 廿七 & & 十一 & 廿五 & 犬戎杀幽王 \\
\hline 779 & 三年 & 廿八 & & & 廿六 & \\
\hline 778 & 四年 & 廿九 & & & 廿七 & \\
\hline 777 & 五年 & 三十 & & & 廿八 & \\
\hline 776 & 六年 & 卅一 & & & 廿九 & \\
\hline 775 & 七年 & 卅二 & & & 三十 & \\
\hline 774 & 八年 & 卅三 & & & 冊一 & \\
\hline 773 & 九年 & 卅四 & & & 卅二 & \\
\hline 772 & 十年 & 卅五 & & 平王元年 & 卅三 & \\
\hline 771 & 十一 & 卅六 & 犬戎杀幽王 & 二年 & 卅四 & \\
\hline
\end{tabular}




\begin{tabular}{|c|c|c|c|c|c|c|}
\hline 年代 & \multicolumn{3}{|c|}{ 《史记》年表 } & \multicolumn{3}{|c|}{ 本文校正 } \\
\hline (公元前) & 周王纪年 & 鲁公纪年 & 备注 & 周王纪年 & 鲁公纪年 & 备注 \\
\hline 770 & 平王元年 & 卅七 & 平王东迁 & 三年 & 卅五 & 平王东迁 \\
\hline 769 & 二年 & 卅八 & & 四年 & 卅六 & \\
\hline 768 & 三年 & 惠公元年 & & 五年 & 惠公元年 & \\
\hline
\end{tabular}

订正后的真公元年在公元前 864 年, 据此向上推算, 献公在位三十二年, 其元年相当于公 元前 896 年; 厉公在位三十七年, 其元年相当于公元前 933 年; 魏公在位五十年, 其元年相当 于公元前 983 年; 幽公在位十四年, 其元年相当于公元前 997 年; 炀公在位六年, 其元年相当 于公元前 1003 年; 考公在位四年, 其元年相当于公元前 1007 年。(1) 康王元年在公元前 1010 年，说明伯禽活到了康王世，与文献中 “炒父、禽父并事康王” 的记载相符。本文推定周公归 政在成王七年，当年伯禽封于鲁。(2) 若以其次年 (相当于公元前 1035 年) 为伯禽元年，则伯禽 在位二十八年。由此可得完整的鲁公年代，总结于表 7。

\begin{tabular}{|c|c|c|c|}
\hline \multicolumn{2}{|c|}{ 鲁公 } & \multirow{2}{*}{$\begin{array}{c}\text { 元年 } \\
\text { ( 公元前) }\end{array}$} & \multirow{2}{*}{ 在位年数 } \\
\hline 号 & 名 & & \\
\hline & 伯禽 & 1035 & 28 \\
\hline 考公 & 酋 & 1007 & 4 \\
\hline 炀公 & 熙 & 1003 & 6 \\
\hline 幽公 & 宰 & 997 & 14 \\
\hline 魏公 & 沸 & 983 & 50 \\
\hline 厉公 & 擢 & 933 & 37 \\
\hline 献公 & 具 & 896 & 32 \\
\hline 真公 & 濞 & 864 & 30 \\
\hline 武公 & 敖 & 834 & 10 \\
\hline \multirow[t]{2}{*}{ 懿公 } & 戏 & 824 & 9 \\
\hline & 伯御 & 815 & 11 \\
\hline 孝公 & 称 & 804 & 36 \\
\hline 惠公 & 弗湟 & 768 & 46 \\
\hline 隐公 & 息 & 722 & 11 \\
\hline
\end{tabular}

\section{《武成》、《世俘》历日与武王伐殷日程表}

武王克纣的具体日期，《武成》说在三月甲子日，《世俘》却说在二月甲子日。而两篇都 记载甲子日在既死霸后五日, 且武王于四月庚戌日回到周地。如果四月有庚戌日, 则甲子日只 能在三月, 不得在二月。《武成》又说武王出发的那天在一月癸巳日。如果一月有癸巳日, 则 甲子日又只能在二月, 不得在三月。若殷历建丑、周历建子, 殷历二月即周历三月。那么癸巳

(1) 以上鲁公在位年数据《史记》卷 33 《鲁周公世家》，第 5 册第 1837 页。

(2) 《尚书・洛诰》: “王命周公后, 作册逸诰。在十有二月, 惟周公诞保文武受命, 惟七年。” 《尚书正 义》卷 15 , 《十三经注疏》, 第 3 册第 494 页。 
日在殷历一月、甲子日在殷历二月、周历三月, 庚戌日则在周历四月。这样看来，《武成》在 克纣的当月即改用周历，故甲子在三月；而《世俘》在克纣的次月才改行周历，故甲子在二 月。(1) 两篇文献称年初第一个月为 “一月” ，与出土的西周金文称岁首第一个月为 “正月” 不 同，但是与出土甲骨文称 “一月” 相同，亦可证其 “一月”为殷历一月。

《世俘》却记载武王出发征商在一月丁巳日。丁巳日至甲子日仅 7 天, 考虑到古代行军的 实际情况以及周地到牧野的距离, 武王出发征商的日期当从《武成》。笔者猜想, 《世俘》的 这条历日可能是武王初次伐殷时的出发日期，而《武成》记载的则是武王克纣当年的出发日 期。

武王克纣的日期推为周受命十三年周历 (亥正) 三月、殷历 (子正 ) 二月甲子，为公元前 1044 年 1 月 9 日。由此上推当年殷历一月壬辰旁死霸在公元前 1045 年 12 月 8 日, 为朔之次 日; 由甲子日下推当年周历四月乙巳既旁生霸在公元前 1044 年 2 月 19 日, 是望日。由此可推 知 “旁死霸” 是朔之次日, 而 “既旁生霸” 是望日。

表 8 武王伐殷日程表

\begin{tabular}{|c|c|c|c|c|c|c|}
\hline 周王纪年 & 殷历 & 周历 & 干支 & 月相 & 日期 (公元前) & 事件 \\
\hline \multirow[t]{2}{*}{ 受命十一 } & 一月 & & 丙辰 & 旁生魄 & 1046 年 1 月 12 日 & \\
\hline & & & 丁巳 & & 1 月 13 日 & 王乃步自于周 (至孟津观兵而归) \\
\hline \multirow[t]{18}{*}{ 受命十三 } & 一月 & & 壬辰 & 旁死霸 & 1045 年 12 月 8 日 & \\
\hline & & & 癸巳 & & 12 月 9 日 & 武王乃朝步自周 \\
\hline & & & 戊午 & & 1044 年 1 月 3 日 & 师渡孟津 \\
\hline & 二月 & 三月 & 庚申 & 既死霸 & 1 月 5 日 & \\
\hline & & & 甲子 & & 1 月 9 日 & 克纣 \\
\hline & & & 丁卯 & & 1 月 12 日 & 望至告以酋俘 \\
\hline & & & 戊辰 & & 1 月 13 日 & 追祀文王、武王立政 \\
\hline & & & 壬申 & & 1 月 17 日 & 荒新至告以首或俘 \\
\hline & & & 辛巳 & & 1 月 26 日 & 至告以首或俘 \\
\hline & & & 甲申 & & 1 月 29 日 & 告以酋或俘 \\
\hline & & 四月 & 乙未 & & 2 月 9 日 & 武王成辟 \\
\hline & & & 庚子 & & 2 月 14 日 & 命陈本、百韦、新荒伐磨、宣方、蜀 \\
\hline & & & 乙巳 & 既旁生魄 & 2 月 19 日 & 陈本、新荒蜀磨至…… \\
\hline & & & 庚戌 & & 2 月 24 日 & 武王朝至燎于周 \\
\hline & & & 辛亥 & & 2 月 25 日 & 荐俘殷王鼎, 祀于天位 \\
\hline & & & 癸丑 & & 2 月 27 日 & 荐殷俘王士百人 \\
\hline & & & 甲寅 & & 2 月 28 日 & 告伐殷于牧野(2) \\
\hline & & & 乙卯 & & 3 月 1 日 & 以庶国祀首或于庙 \\
\hline
\end{tabular}

(1) 见李学勤: 《〈世俘〉篇研究》, 王元化主编: 《古文献从论》, 第 73 页。

(2) 此句改 “谒戎殷于牧野” 为 “告伐殷于牧野”, 详见李学勤: 《〈世俘〉篇研究》, 王元化主编: 《古文献 从论》, 第 72 页。 
又据参考历谱，周受命十一年殷历子正一月、周历亥正二月癸印朔、丁巳望，丙辰在望前 一日，为公元前 1046 年 1 月 12 日。上面已推得 “既旁生魄” 为望日，其月相恰在此 “旁生 魄”后一日。这个结果说明《世俘》与《武成》的历日信息可以自洽。

《世俘》另外记载了武王伐纣过程中的多条历日。本文除了将 “一月丙辰旁生魄, 若翼日 丁巳” 置于受命十一年之外, 其余历日均采用李学勤先生的编排方案。(1) 此外, 《泰誓书序》 载: “惟十有一年, 武王伐殷。一月戊午, 师渡孟津。” 2 由于戊午日就在丁巳日之次日, 此

“一月戊午” 不应在受命十一年, 而当在受命十三年。由此可得武王伐殷的完整日程表，如表 8 所示。

\section{晚出《泰誓》的年代信息不伪}

《史记・周本纪》记载武王初次伐殷在周受命九年，两年后受命十一年克纣。(3) 太史公依 据的材料应该就是《泰誓书序》，以十有一年为武王克纣之年。

晚出《尚书》中有《泰誓》三篇，一般认为是后人托伪之作。然而，笔者注意到，其《泰 誓》上篇开篇说 “惟十有三年春, 大会于孟津” , 显然是认为武王克约在受命十三年。《尚书 孔氏传》解此句说 “此周之孟春” 。孔颖达为此句作疏, 还特意强调: “ “惟十有三年春” 或 作 “十有一年” , 后人妄看序文辄改之。” (4) 若周历子正, 而以建寅之月为孟春, 当在周历三 月。根据上一小节推算的武王伐殷日程（表 8)，周受命十三年殷历一月戊午在周历三月既死霸 前两天，可称 “惟十有三年春”。

晚出《尚书》二十五篇的文字已考证出来并非上古原典, 近代以来多视其为伪作, 是以本 文在推算年代时并未采纳晚出《尚书》的内容。然而, 《泰誓上》的记载却能与本文的推算结 果相合, 意味着其所载年代信息可以得到金文历日的支撑, 是可信的。据笔者所知, 记载武王 克纣在受命十三年, 仅见于此篇。如果系后人伪作, 那么作伪者也掌握了武王克纣的真实历日 信息，其来源很可能就是《汲冢竹书》。

推而论之, 既然晚出《尚书》的作者很可能见到过《汲冢竹书》, 那么其余篇章中的年代 信息也应当引起重视。例如：晚出《武成》记述文王受命九年崩，当年武王即位未改元。(5) 准 此，则武王即位在公元前 1048 年。

\section{既死霸是一月之始}

晋侯鮴钟的铭文历日中，“二月既死霸壬寅”与 “六月初吉戊寅”均在宣王三十四年。由 于初吉是虚拟历日，那么六月不能出现戈寅日。从壬寅日至戊寅日，历 $36+60 \times \mathrm{N}(\mathrm{N} \geqslant 0)$ 日。从二月朔日到六月朔日，历四个朔望月。当 $\mathrm{N}$ 取 1 时，壬寅日至戊寅日历 96 天，以一个朔 望月平均约 29.53 日计, 合三个月又 7 日余。要使得二月有壬寅日而六月无戊寅日, 那么既死霸

(1) 李学勤: 《〈世俘〉篇研究》, 王元化主编: 《古文献从论》第 72-73 页。

(2) 《尚书正义》卷 11, 《十三经注疏》, 第 3 册第 317 页。

(3) 《史记・周本纪》: “九年, 武王上祭于毕。东观兵, 至于盟津……万还师归。居二年……以东伐纣。十一 年十二月戊午, 师毕渡盟津, 诸侯咸会。” 《《史记》卷 4 , 第 1 册第 $156-157$ 页。

(4) 《尚书正义》卷 11 , 《十三经注疏》, 第 3 册第 320 页。

(5) 《尚书・武成》: “惟九年, 大统未集。” 《《尚书正义》卷 11, 《十三经注疏》, 第 3 册第 344 页。 
不能在月末。如果既死霸不在月末，就说明西周历法不是以朏日（或朏之次日 ) 作为月初, 那 公既死霸宜在月初。这意味着西周时即以月之亮面消失为一个月之始, 大概在晦日与朔日之间 浮动, 与后世所行历法已经十分接近。

这一推论也与文献的记载一致。如, 据《武成》, 周历三月既死霸为庚申日, 而据《世 俘》, 四月有乙未日。从庚申日至乙未日, 历 $35+60 \times \mathrm{N}(\mathrm{N} \geqslant 0)$ 日。当 $\mathrm{N}$ 取 0 时, 庚申 日至乙未日相差 35 天, 合一个月又 5 日余。而四月既旁生霸是乙巳日, 在乙未日后十日（见表 8 ）。如此，则三月既死霸庚申也只能在月初，不能在月末。

又如，《召诰》有历日 “三月丙午朏” ，《洛诰》曰，“戊辰……在十有二月”。两篇均 记成王七年周公归政之事, 系同年。由丙午日至戊辰日，历 $22+60 \times \mathrm{N}(\mathrm{N} \geqslant 0)$ 日。由三月 朔至十二月朔，历九个朔望月。当 $\mathrm{N}$ 取 4 时，丙午日至戊辰日相差 262 天，合八个月又 25 日 余，差约 3-4 天足九个月。这说明戊辰日的月相比十二月朏提前约 3 日余。若西周历法以朏日 为月初, 那么戈辰日只能在十一月底, 不能在十二月。朏日在朔日之后 1-2 天, 那么推算十二 月戊辰的月相约在朔前一日, 即晦日。这也与西周历法以既死霸为月初的结论相合。

\section{虢季子白盘非宣王器}

虢季子白盘, 《集成》定在西周晚期, 往者多以为宣王器。其铭文历日为“唯十又二年正 月初吉丁亥”。本文推算宣王十二年在前 825 年，当年子正正月庚戌朔 (前 826 年 12 月 17 日 07:15:33 合朔），则当月无丁亥日，可以与虢季子白盘铭文历日建正相合。然而，此前已将大篮 盖排入宣王世，其铭文历日与宣王十二年错月相合，则虢季子白盘与大笽盖的历日不能置于同 一年。夷王、孝王的在位时间都不足十二年，懿王十二年虽然也可以和大篮盖铭文历日相合， 但是其时代太早。则大笽盖必须置于宣王十二年才合理。这就将虢季子白盘排除出宣王世。

据杨博先生考辨，(1) 虢季子白盘的纹饰更类似于春秋初期的青铜器，字体风格也更接近于 春秋时期秦国文字。其铭文文体基本上是四字韵文，与宣王时期的兮甲盘及佐鼎铭文不同。对 照金文与文献材料中的记载，推测虢季子白很可能就是在幽王死后拥立携王的 “虢公翰”。(2) 因此本文将虢季子白盘置于携王十二年。

\section{余论}

本文的周王年代方案有不少年份存在错月的现象。这说明参考历谱根据冬至确定的岁首正 月与金文历日记录的实际西周历谱有误差。笔者猜想西周时有可能通过观察北斗斗柄的指向， 也就是 “斗建” ，来确立岁首以及添置闰月。而如何定量计算斗建仍有待进一步的探索。确立 了计算斗建的方法之后，就可以由金文历日检验西周历法是否根据斗建确立岁首。

文献中的月相术语与金文记日用语颇异。以本文的推算结果观之，文献中的记日用语比金 文记日用语对月相的划分更精细。笔者猜想，一个可能的原因是文献与金文的功用不同：文献 记录的多为史事，其所用的月相术语用于记时；而金文记录的多为祭祀、册赐礼仪，其所用的

(1) 杨博: 《虢季子白盘的年代及相关历史问题考述》, 《Journal of Chinese Writing Systems》2018 年第 4 期。

(2) 《汲冢竹书》: “幽王既死, 而虢公翰又立王子余臣于携。周二王并立。”、“幽王死, 申侯、鲁侯、许文 公立平王于申, 虢公翰立王子余, 二王并立。” 见方诗铭、王修龄撰: 《古本竹书纪年辑证》, 第 63 - 64 页。 
记日用语或与下筮吉日相关。这或许可以解释文献与金文记日用语的差异。否则，如果文献中 的月相术语系后出，则意味着文献记载的历日信息并非当时的原始记录，那么其可信度会降 低。因此，文献中的月相术语和金文记日用语的关系亟待厘清。

《史记》年表中, 自鲁隐公三年以上的年代有误。本文已校正了周王和鲁公纪年, 而其余 诸侯的年代应如何调整，仍需进一步的研究。

\section{结语}

综上，本文通过系统性地推算、检索、比对 81 条四要素俱全的金文历日，推算、考证得自 文王至夷王的年代，校正了厉王、宣王、幽王、平王的年代，并增补了携王年代，补足了周代 纪年，由此可将中国历史的确切纪年上溯至文王受命元年（相当于公元前 1056 年）。

本文的推算结果与出土材料、文献资料以及古代天象均可高度契合，而局部仍有小幅调整 的余地。如，夷王元年有公元前 $881 、 880 、 879$ 年三解，本文因公元前 881 年可与师訇笽铭文历 日建正相合而取为夷王元年; 又如，部分初吉历日的王世安排或可调整。这都可由进一步的研 究或者新的考古发现来检验与修正。然而, 这些局部的调整对本文提出的年代方案的整体结构 影响不大。

本文的推算结果可以为古史研究提供可靠的年代框架, 并为继续向上追溯殷商年代提供支 点, 有助于进一步探究中华文明的起源。希望本文提出的方法与结论能够为先秦史研究提供有 益的参考。

\section{致谢}

古联 (北京) 数字传媒科技有限公司与北京北大方正电子有限公司提供的中华书局宋体字 库，为本文的书写提供了极大的便利，特此感谢。 